\title{
25 Can Verification Report for the LLNL Plutonium Packaging System (PuPS)
}

\author{
D. Riley, K. E. Dodson
}

May 7, 2001

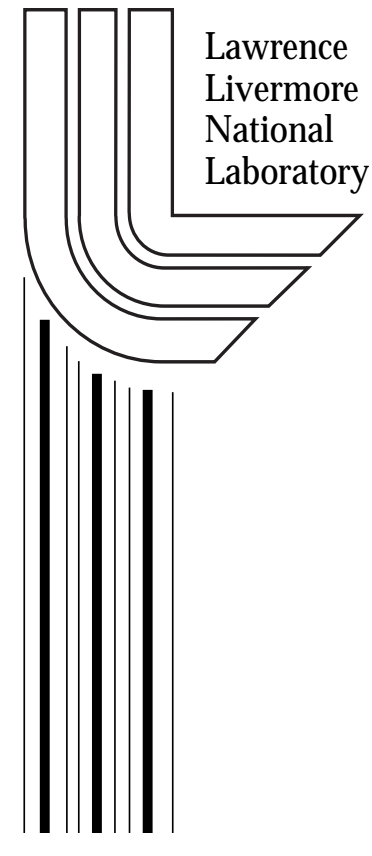




\section{DISCLAIMER}

This document was prepared as an account of work sponsored by an agency of the United States Government. Neither the United States Government nor the University of California nor any of their employees, makes any warranty, express or implied, or assumes any legal liability or responsibility for the accuracy, completeness, or usefulness of any information, apparatus, product, or process disclosed, or represents that its use would not infringe privately owned rights. Reference herein to any specific commercial product, process, or service by trade name, trademark, manufacturer, or otherwise, does not necessarily constitute or imply its endorsement, recommendation, or favoring by the United States Government or the University of California. The views and opinions of authors expressed herein do not necessarily state or reflect those of the United States Government or the University of California, and shall not be used for advertising or product endorsement purposes.

This work was performed under the auspices of the U. S. Department of Energy by the University of California, Lawrence Livermore National Laboratory under Contract No. W-7405-Eng-48.

This report has been reproduced directly from the best available copy.

Available electronically at http://www.doc.gov/bridge

Available for a processing fee to U.S. Department of Energy

And its contractors in paper from

U.S. Department of Energy

Office of Scientific and Technical Information

P.O. Box 62

Oak Ridge, TN 37831-0062

Telephone: (865) 576-8401

Facsimile: (865) 576-5728

E-mail: reports@adonis.osti.gov

Available for the sale to the public from

U.S. Department of Commerce

National Technical Information Service

5285 Port Royal Road

Springfield, VA 22161

Telephone: (800) 553-6847

Facsimile: (703) 605-6900

E-mail: orders@ntis.fedworld.gov

Online ordering: http://www.ntis.gov/ordering.htm

OR

Lawrence Livermore National Laboratory

Technical Information Department's Digital Library

http://www.llnl.gov/tid/Library.html 


\section{Can Verification Report for the \\ LLNL Plutonium Packaging System (PuPS)}

Revision 0

May 7, 2001

Prepared by:

David Riley

Date

PuPS Principal Investigator

Approved by:

Karen E. Dodson

Date

PuPS LLNL Project Manager 


\subsection{Summary}

This document reports the results of the 25 Can Verification Run. The 25 Can Verification Run was performed as outlined in Section 1.d of SRS Acceptance Criteria (Reference 1). The run was performed over the period of February 16 to the 28, 2001. Each of these cans was welded with a dummy Inner Can containing about $5 \mathrm{~kg}$ of surrogate material. The cans were then analyzed using radiography and metallography of samples taken at four locations of the weld. The radiographs were examined for porosity. The micrographs of the metallurgical samples were examined for porosity, cracks, and lack of fusion. The results were reviewed by Derrill Rikard (a level 3 inspector at LLNL) and by Ken Durland (a level 3 inspector from WSRC). These reviews did not find anything of concern. Therefore we are submitting these results to SRS for concurrence.

\subsection{Background}

Section 1.d of the SRS Acceptance Criteria (Reference 1) states the following:

The system closure weld repeatability shall be demonstrated by performing full volumetric examinations and evaluations of the final closure weld of the Outer Cans, in accordance with ASME Section VIII Division 1, UW-51. Currently the capability does not exist to perform an ASME acceptable 100\% radiograph of the closure weld from the outside of the outer can. Therefore, this requirement could only be met by producing a dummy outer can, with no radioactive contents, so that the lid could be separated from the side wall, and an ASME acceptable 100\% radiograph be performed from the inside of the closure weld. These dummy outer cans shall be welded following the current qualified welding procedure, visually examined per code, and helium leak tested the same as the regular production cans in the system. Radiographic film shall be interpreted by personnel who are Level III certified in radiography per the American Society for Nondestructive Testing, Inc. (ASNT) "Recommended Practice for Nondestructive Testing Personnel Qualification and Certification," SNT-TC-1A. In addition, the weld shall be cross-sectioned in at least four (4) locations to include the stop-start area, be suitably etched and visually examined at a minimum 10X magnification. The weld and heat-affected-zone shall be examined to ensure complete penetration of the joint, and freedom from cracks and lack of fusion. The dummy outer can shall include a dummy inner can with surrogate material, replicating the approximate size, volume, and weight of a production inner can. The shipper shall produce 25 dummy outer cans successfully welded and tested the same as stated above, and then a maximum of every $25^{\text {th }}$ outer can during production. After the first 100 successful production cans, the shipper may review and change the frequency of the dummy can duration with SRS concurrence (Appendix B, Item 2). All of the dummy outer can test results of the evaluation as well as the radiographs for the full volumetric examinations shall be submitted to SRS for review and concurrence (Appendix $\mathrm{B}$, Item 3). The dummy can test results and radiographs representing the previous production duration must be reviewed and concurred by SRS before 
shipping that production duration of cans. SRS will complete the evaluation within five business days after receipt of the data and reports. If the evaluation results indicate that the outer can weld does not meet acceptance criteria of ASME Section VIII, Division 1, SRS shall participate in the disposition decision of those previous cans (Appendix B, Item 4).

This report only deals with the 25 Can verification Run in this section.

\subsection{Performance of welding}

The Outer Cans used for the 25 Can Verification Run were manufactured by Westinghouse Engineered Products Division (EPD). The 25 cans were welded using weighted BNFL Convenience Cans as the dummy Inner Can. The BNFL Convenience Can was selected for ease in working with security. This testing required the movement of the weighted Inner Cans into and out of the Plutonium Facility. Using the BNFL Convenience Cans allowed the guards to examine the inside of the convenience cans when they were brought into the Radioactive Management Area (RMA). The dummy Inner Cans were weighted to match the weight of an Inner Can, convenience can and $5 \mathrm{~kg}$ of oxide powder. Just prior to welding the first verification can, the welding parameters were rechecked and recorded. This was also done at the end of the verification run.

The 25 cans were welded from February 16 to 28,2001 . The cans that were welded were etched with the following serial numbers:

$\begin{array}{llll}\text { L000004 } & \text { L000020 } & \text { L000028 } & \text { L000036 } \\ \text { L000014 } & \text { L000022 } & \text { L000029 } & \text { L000037 } \\ \text { L000016 } & \text { L000024 } & \text { L000030 } & \text { L000038 } \\ \text { L000017 } & \text { L000025 } & \text { L000031 } & \text { L000040 } \\ \text { L000018 } & \text { L000026 } & \text { L000032 } & \text { L000045 } \\ \text { L000019 } & \text { L000027 } & \text { L000033 } & \text { L000046 } \\ & & & \text { L000047 }\end{array}$

After the cans were welded, they were taken out of the RMA and the tops were cut off so that the weld area was intact. These tops were then sent for radiographs. The radiographs were performed per the DOE-STD-3013-99 Container Test Weld Radiographic Procedure (Reference 2). After the analysis of the radiographs was complete four samples were taken for metallography by sawing pie shaped sections from the weld area. The samples were taken at the overlap (O), ramp down (R), tiein (T), and body (B) locations. These were polished, etched and micrographs taken of them at either $25 \mathrm{X}$ or $20 \mathrm{X}$.

\subsection{Analysis}

Earl Updike (Level II) and Derrill Rikard (Level III) produced and reviewed the radiographs for LLNL. They recorded their results on the LLNL Radiographic Inspection Report. Copies of the reports are included in Appendix A. 
After we had all of the radiographs completed and most of the micrographs complete, Ken Durland of WSRC came to LLNL to review the radiographs. He reviewed them and initialed the Radiological Inspection Records. He also looked at micrographs from 20 of the welded cans that were complete and available. After he left, the remaining micrographs of the final five cans were completed and emailed to him for his review. The actual micrographs were scanned into the computer and are included in Appendix B.

\subsection{Results}

The radiographs and micrographs show that the welding process makes ASME VIII acceptable welds and that it is reliable because it was used on 25 cans sequentially.

\subsection{References}

1) "Savannah River Site Stabilization and Packaging Requirements for Plutonium Bearing Materials for Storage," G-ESR-G-00035, Revision 1, July 26, 2000.

2) “Radiographic Procedure, DOE-STD-3013-99 Container Test Welds," UCRL-MI142273, Lawrence Livermore National Laboratory. 
Appendix A: LLNL Radiographic Inspection Reports for Cans 
L000004 
L000014 
L000016 
L000017 
L000018 
L000019 
L000020 
L000022 
L000024 
L000025 
L000026 
L000027 
L000028 
L000029 
L000030 
L000031 
L000032 
L000033 
L000036 
L000037 
L000038 
L000040 
L000045 
L000046 
L000047 


\section{Appendix B: Micrographs of Metallurgical Samples}

L000004
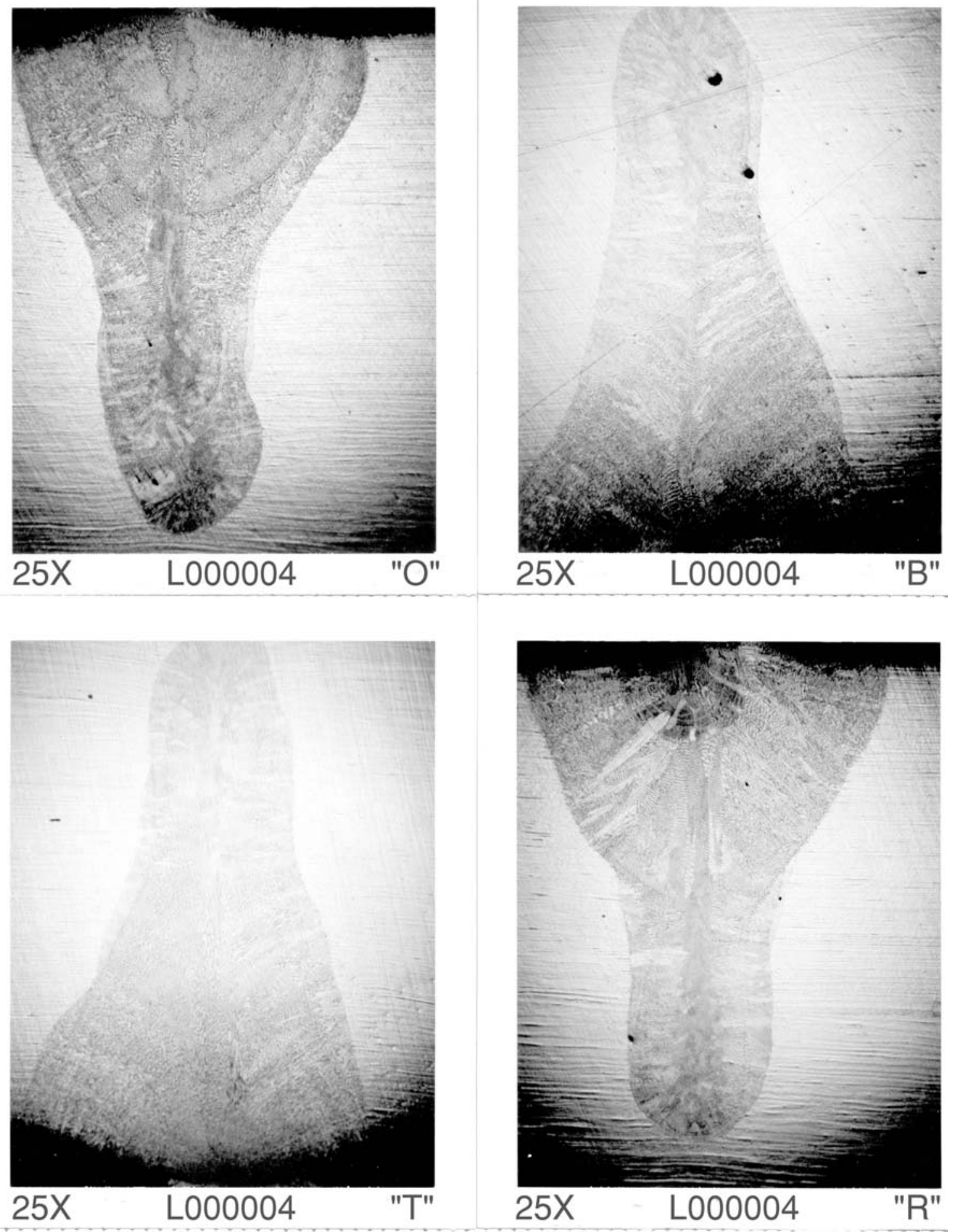
L000014
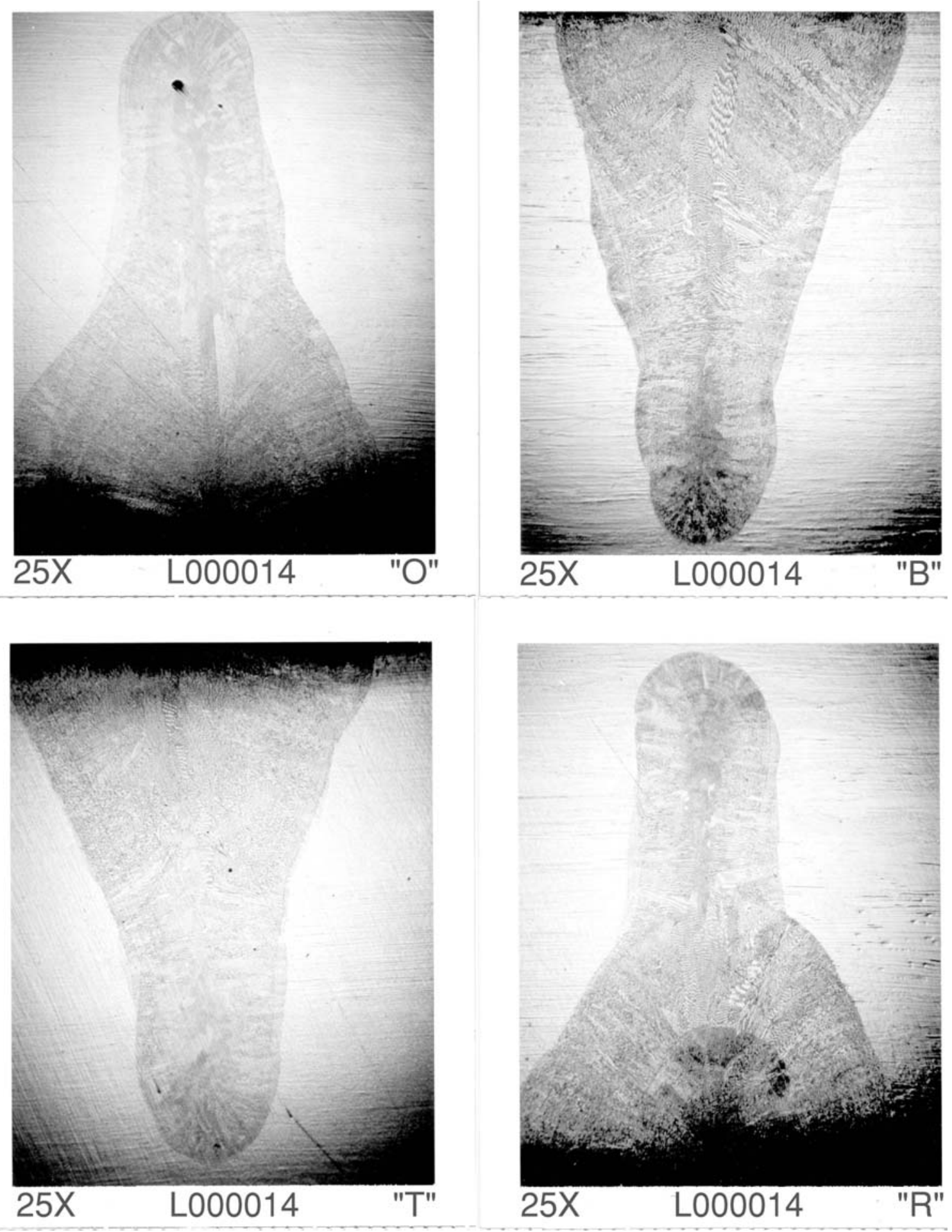
L000016
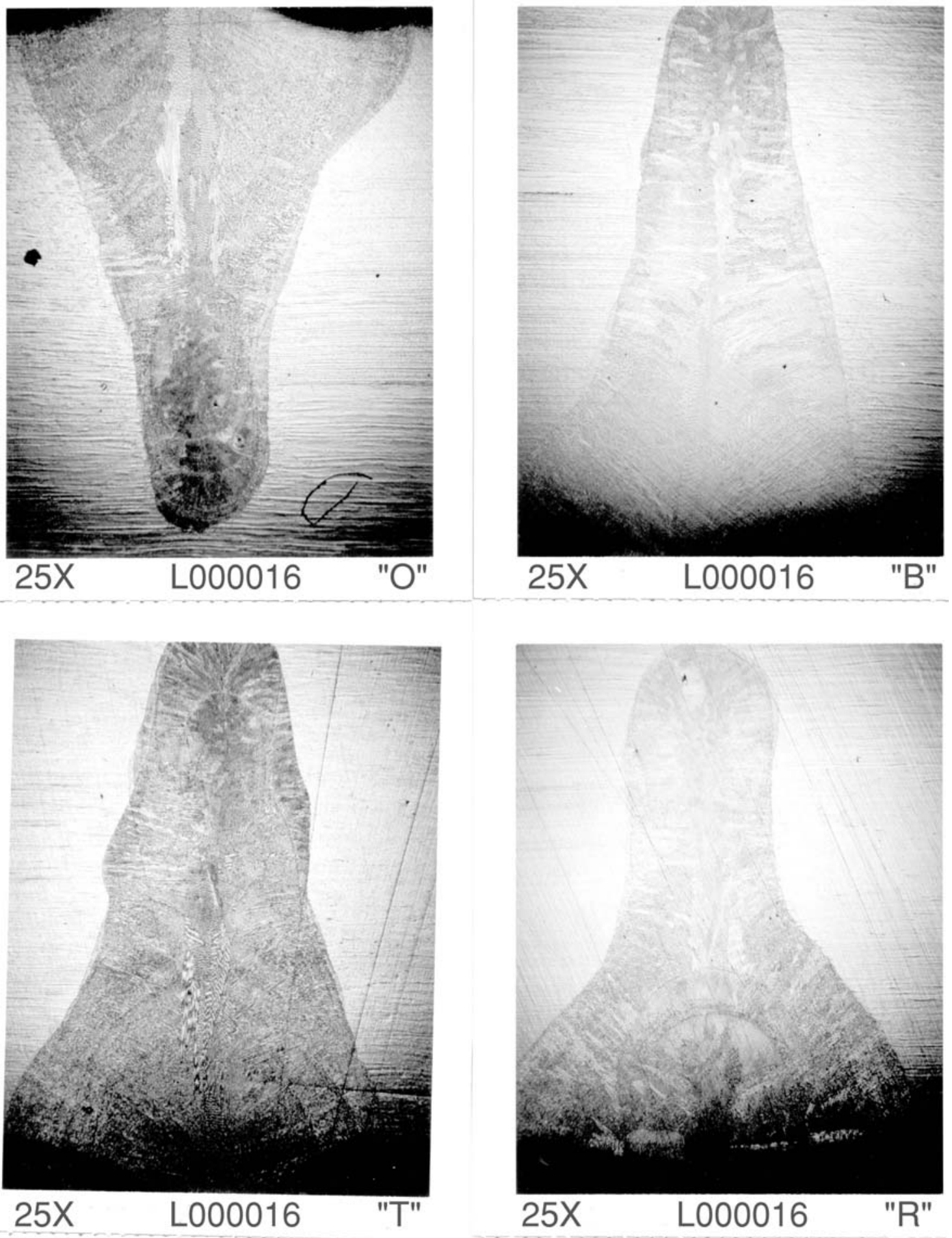
L000017
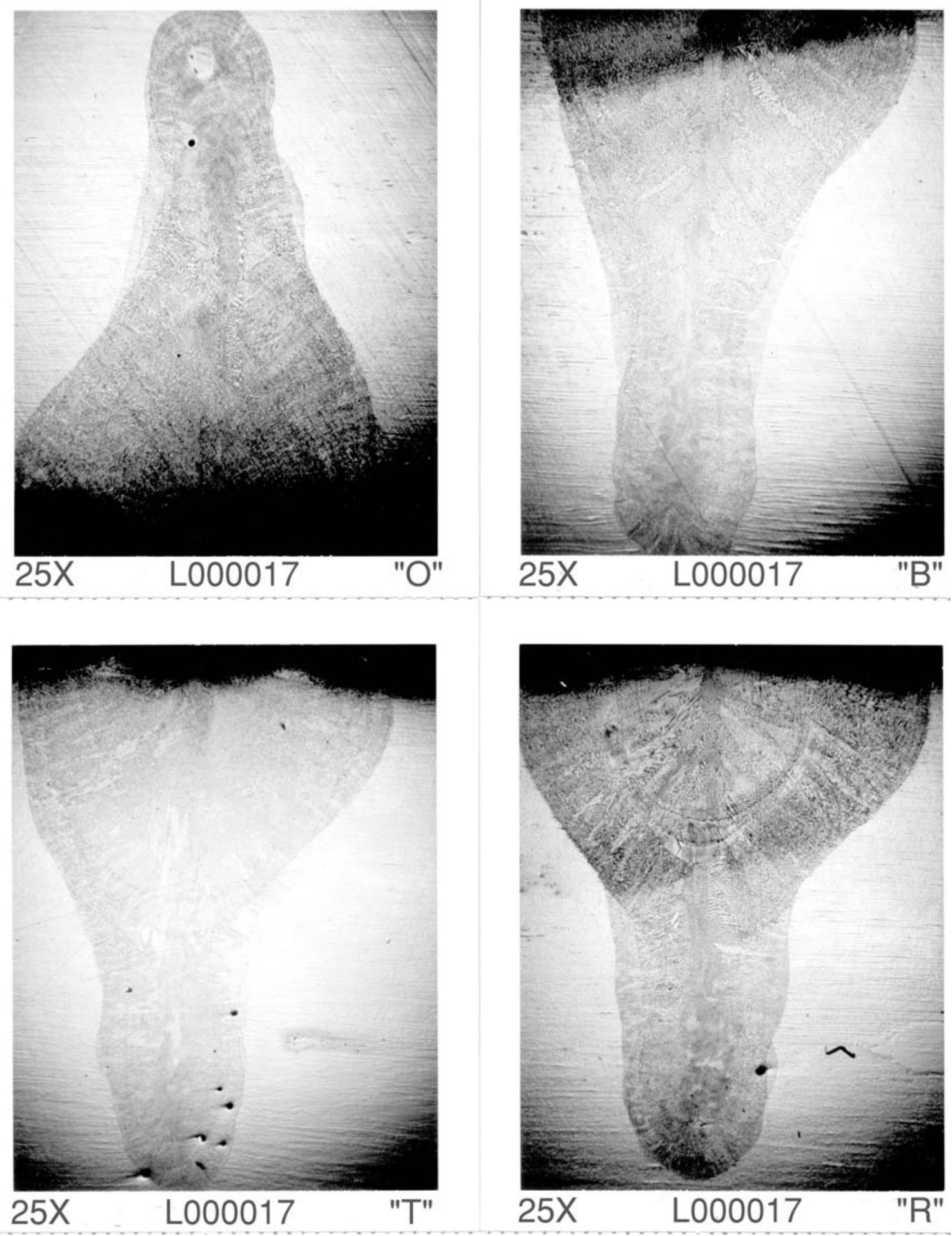
L000018
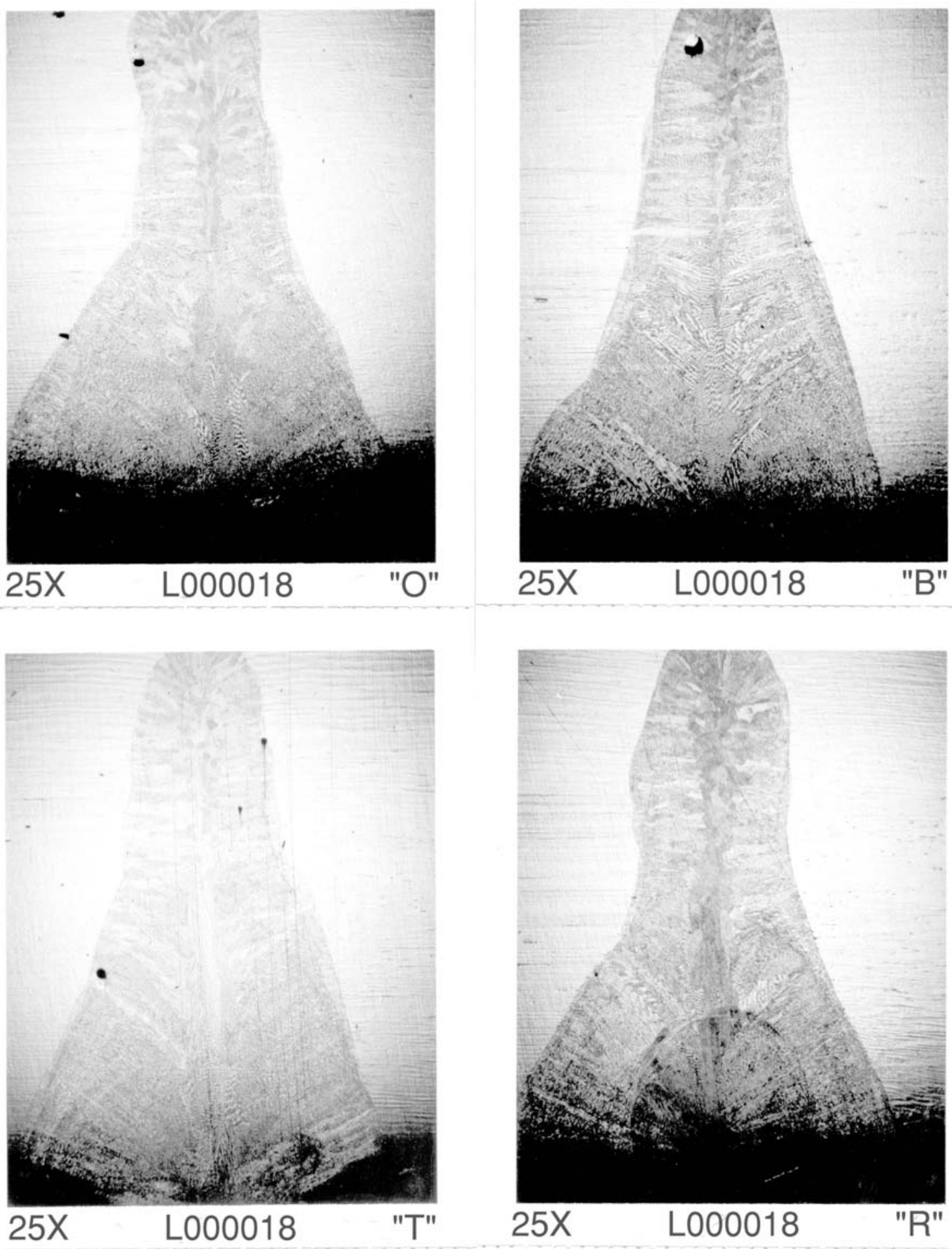
L000019
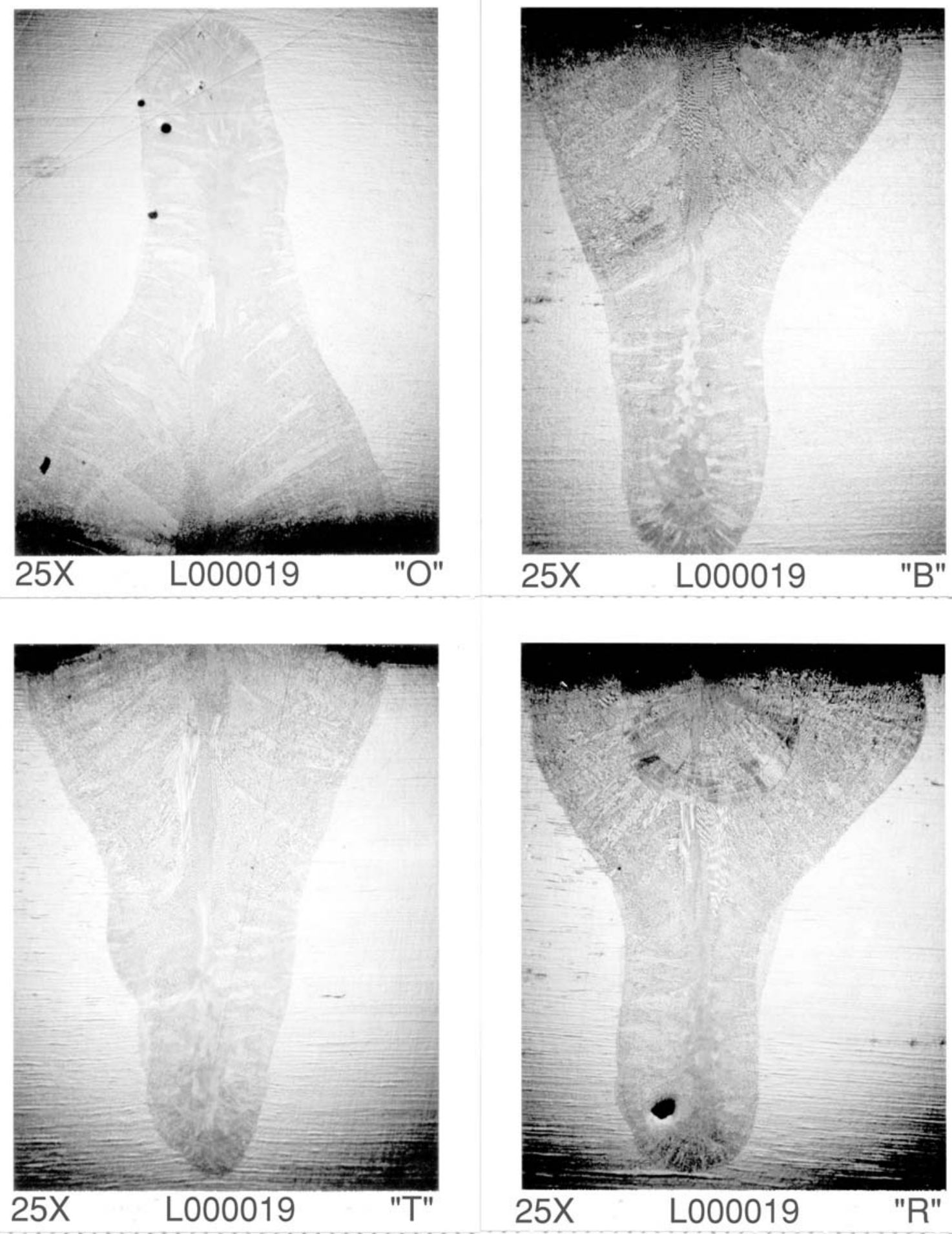
L000020
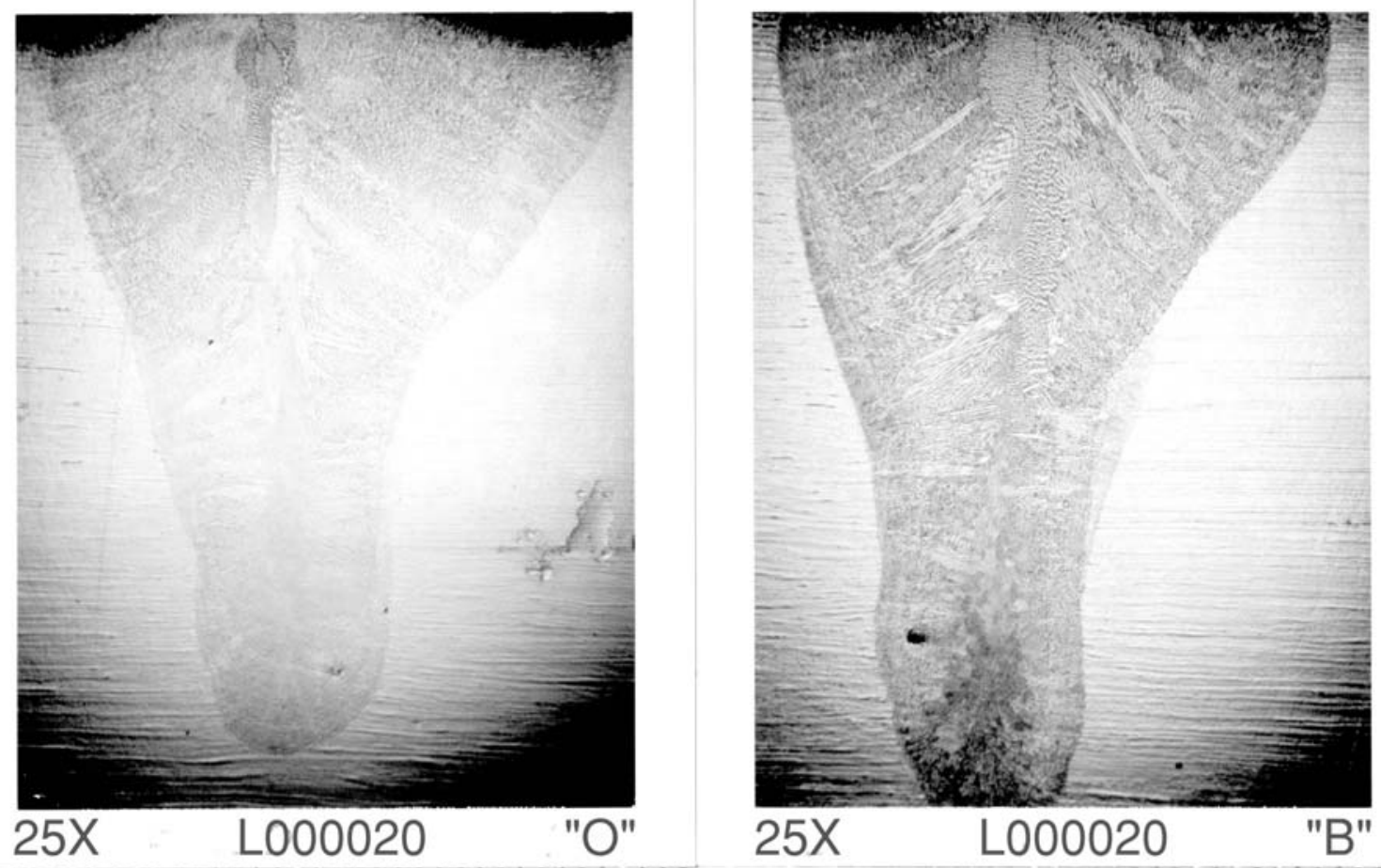

25X L000020 "B"
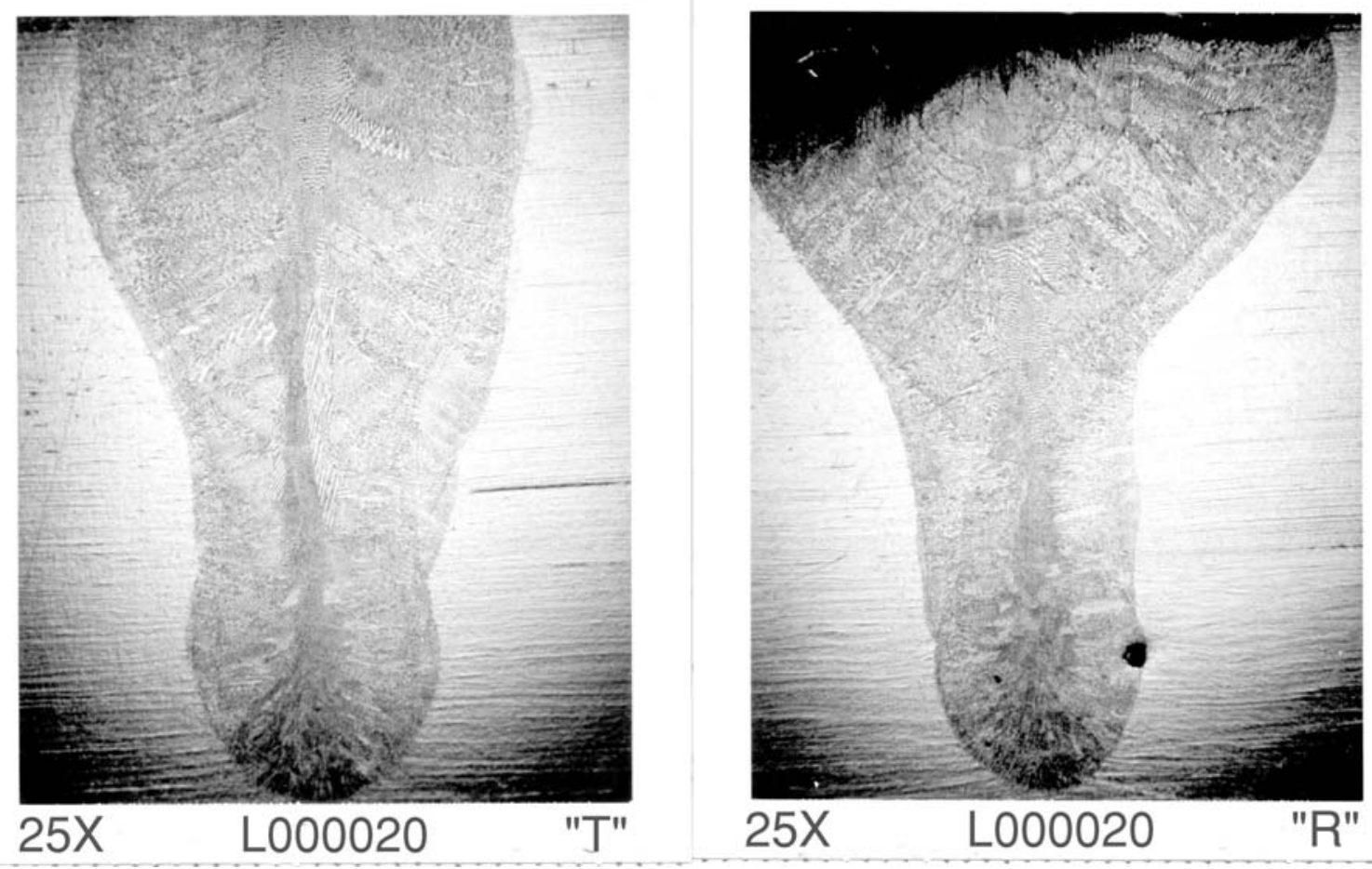
L000022

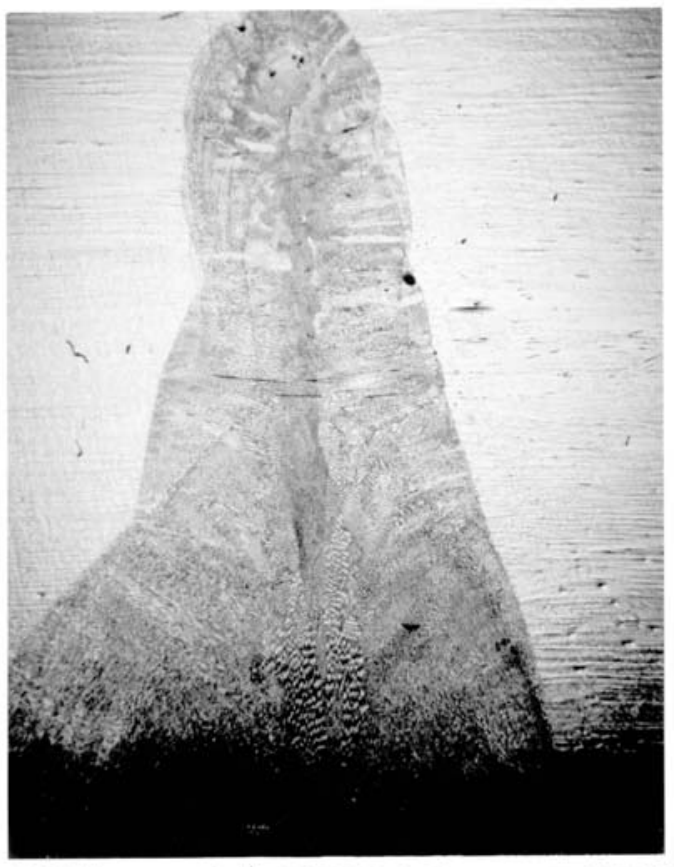

25X L000022

"O"
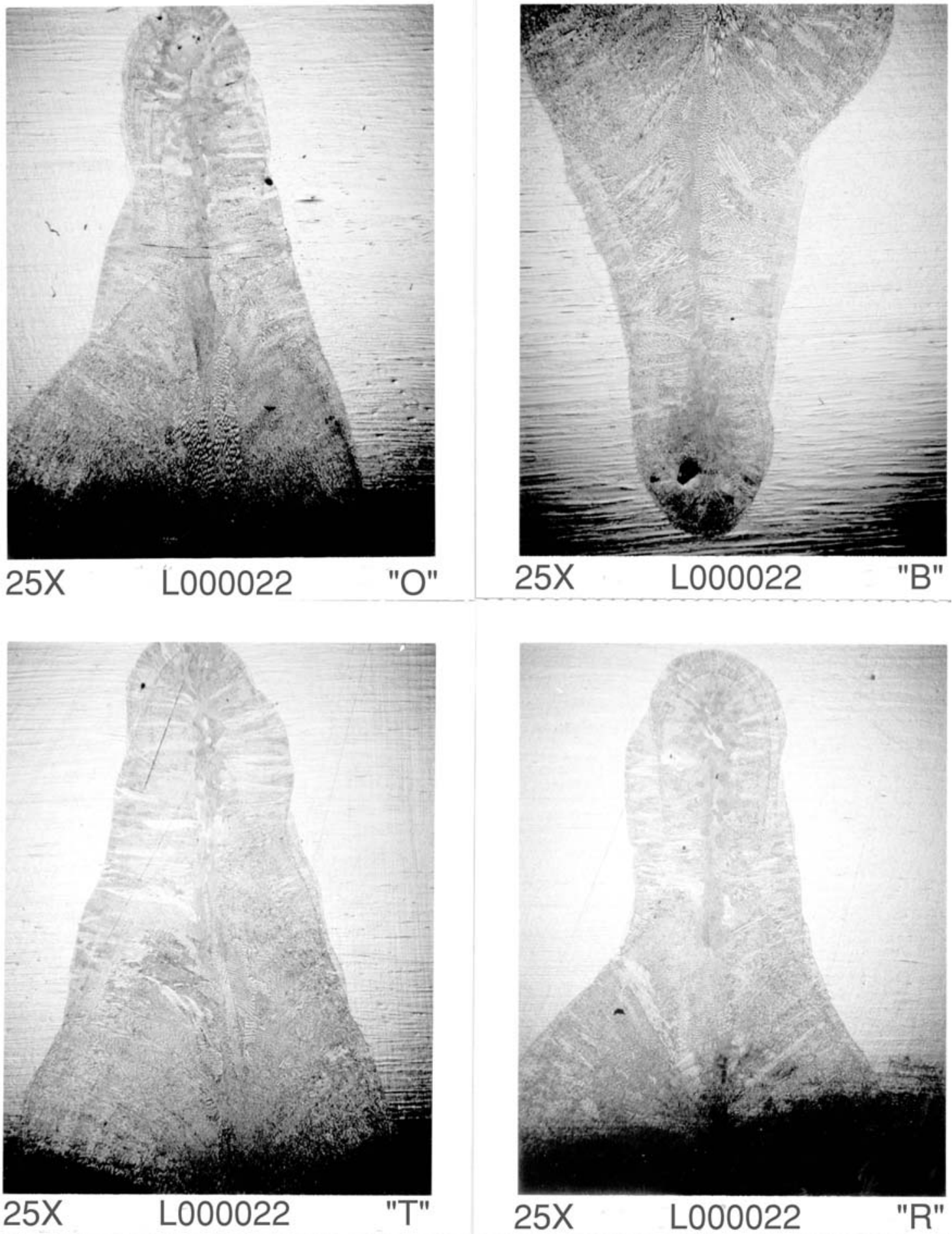
L000024
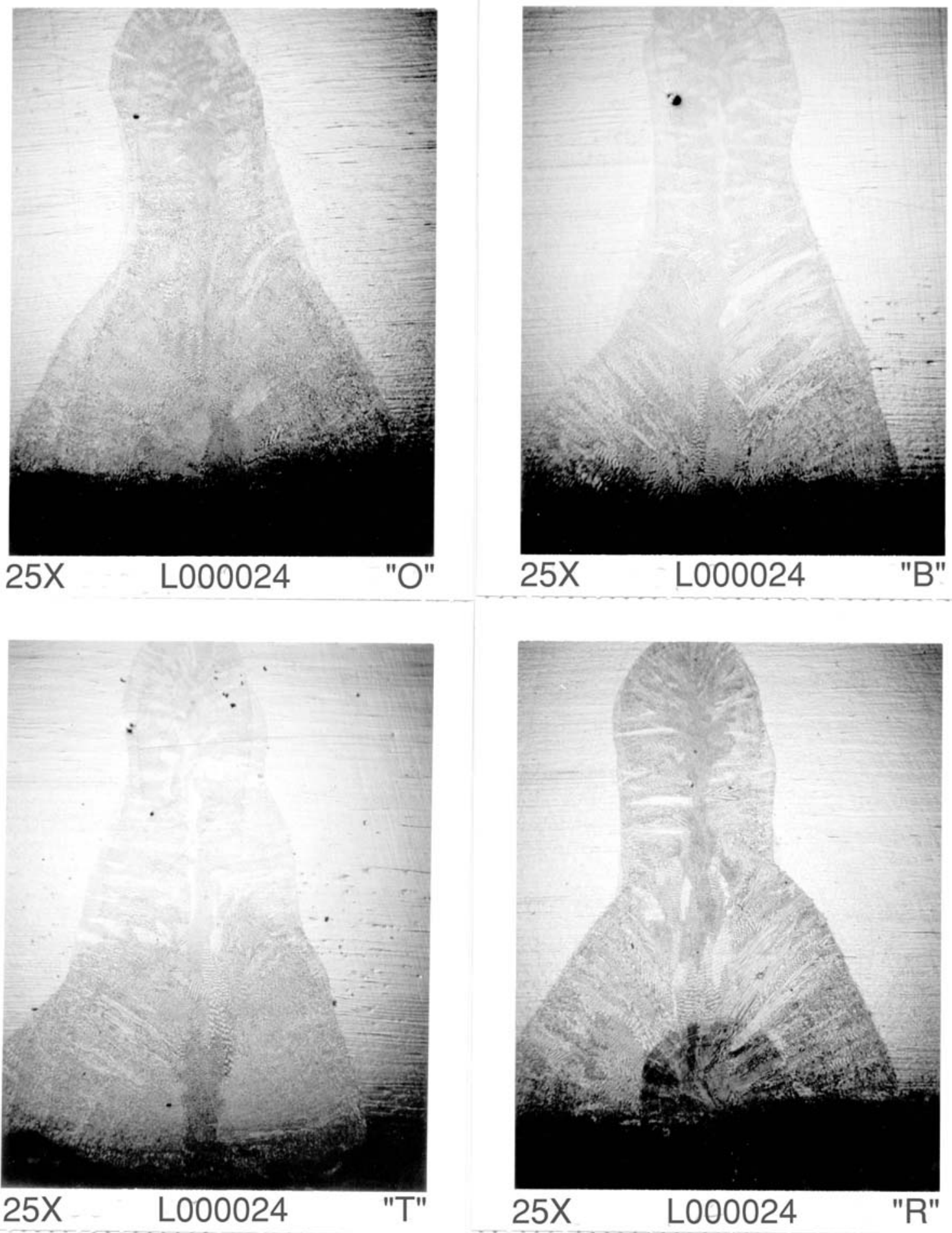
L000025
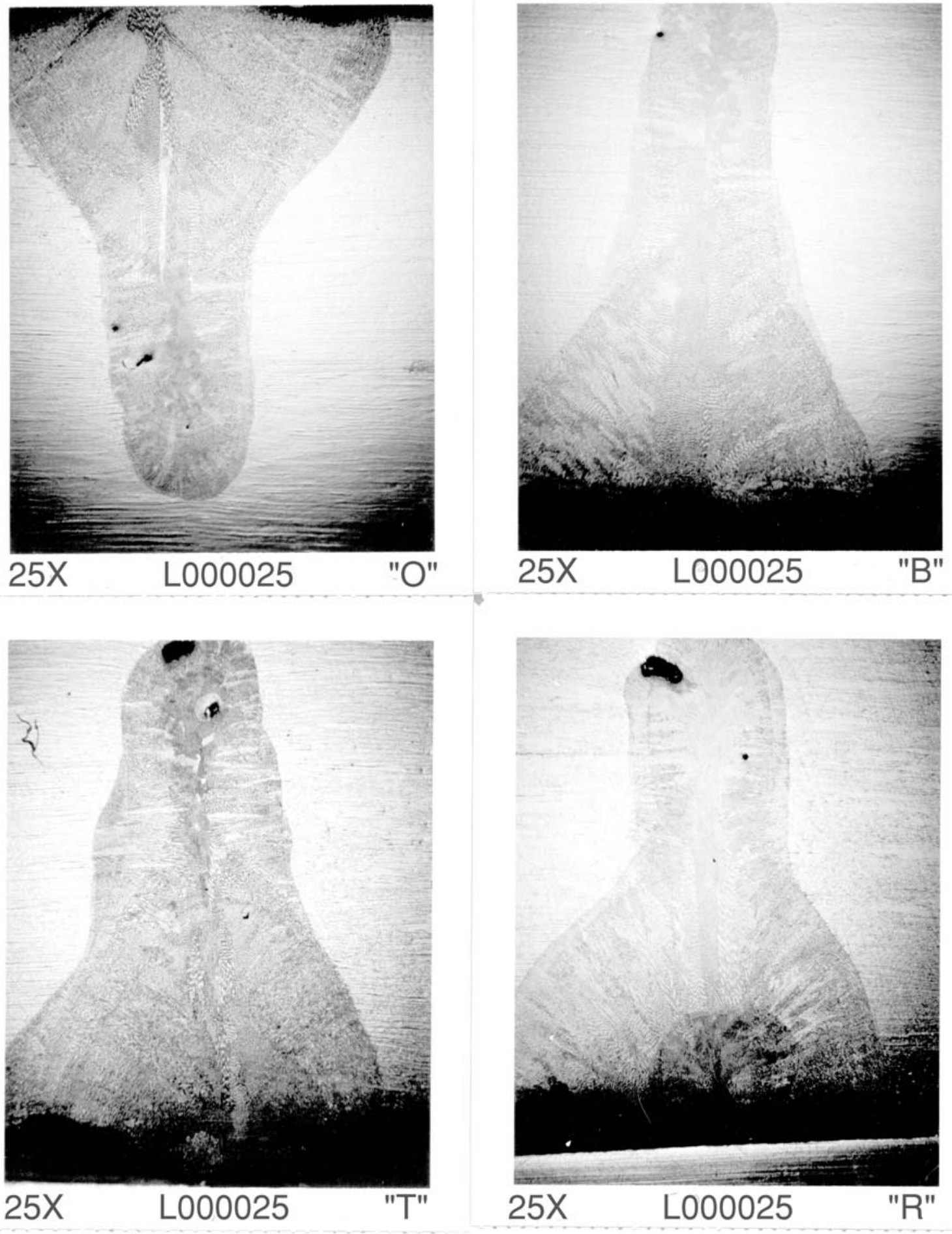
L000026
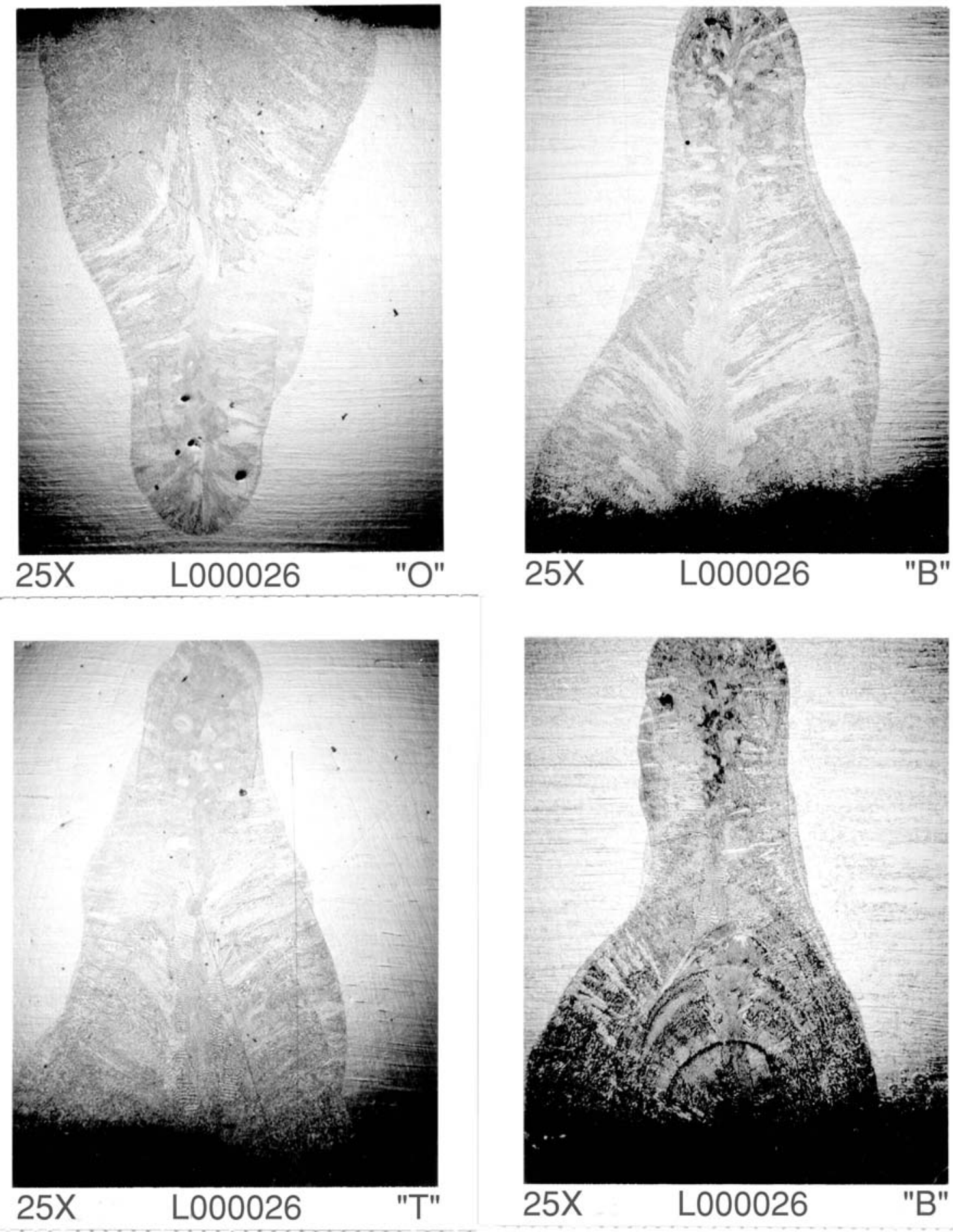
L000027
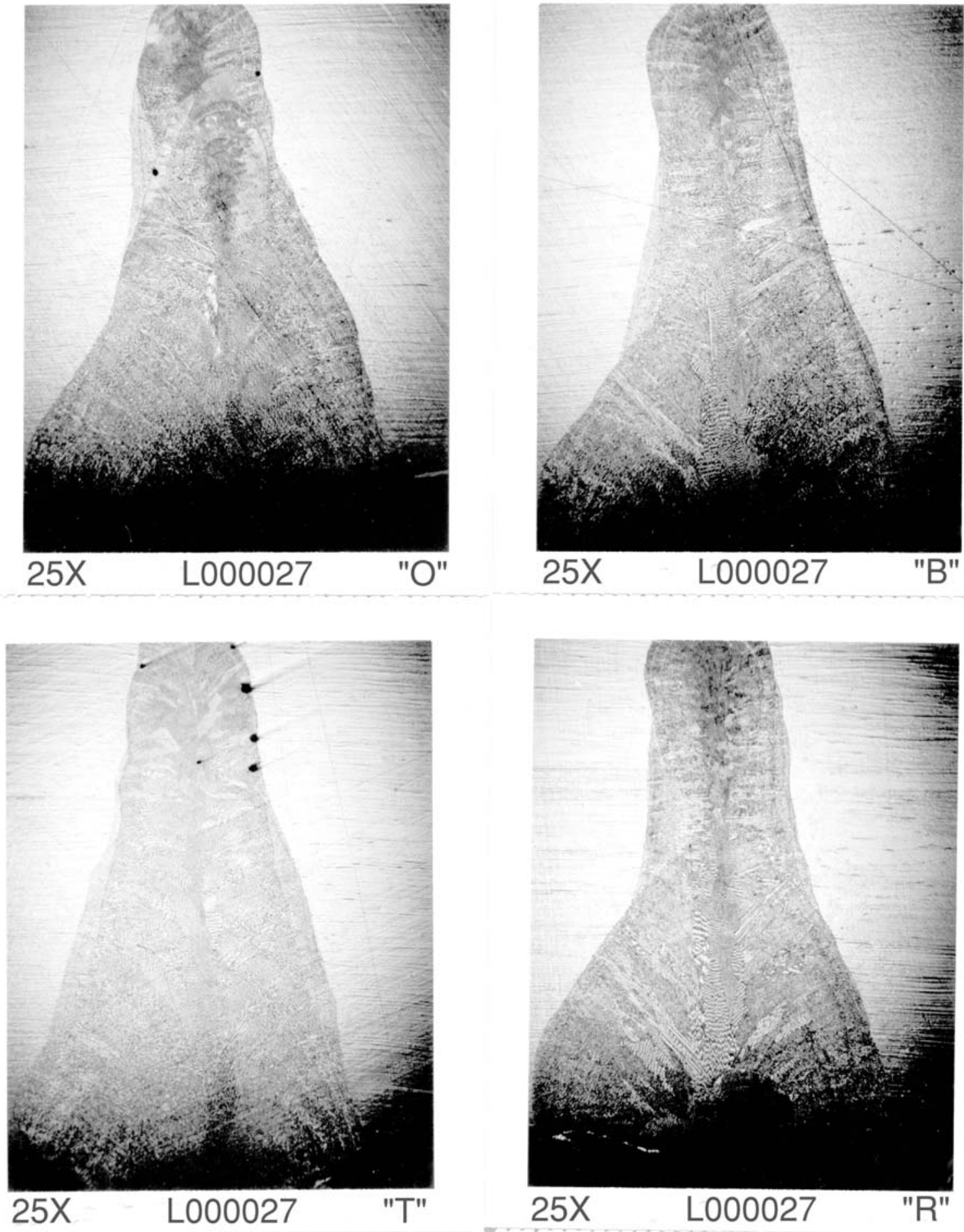
L000028
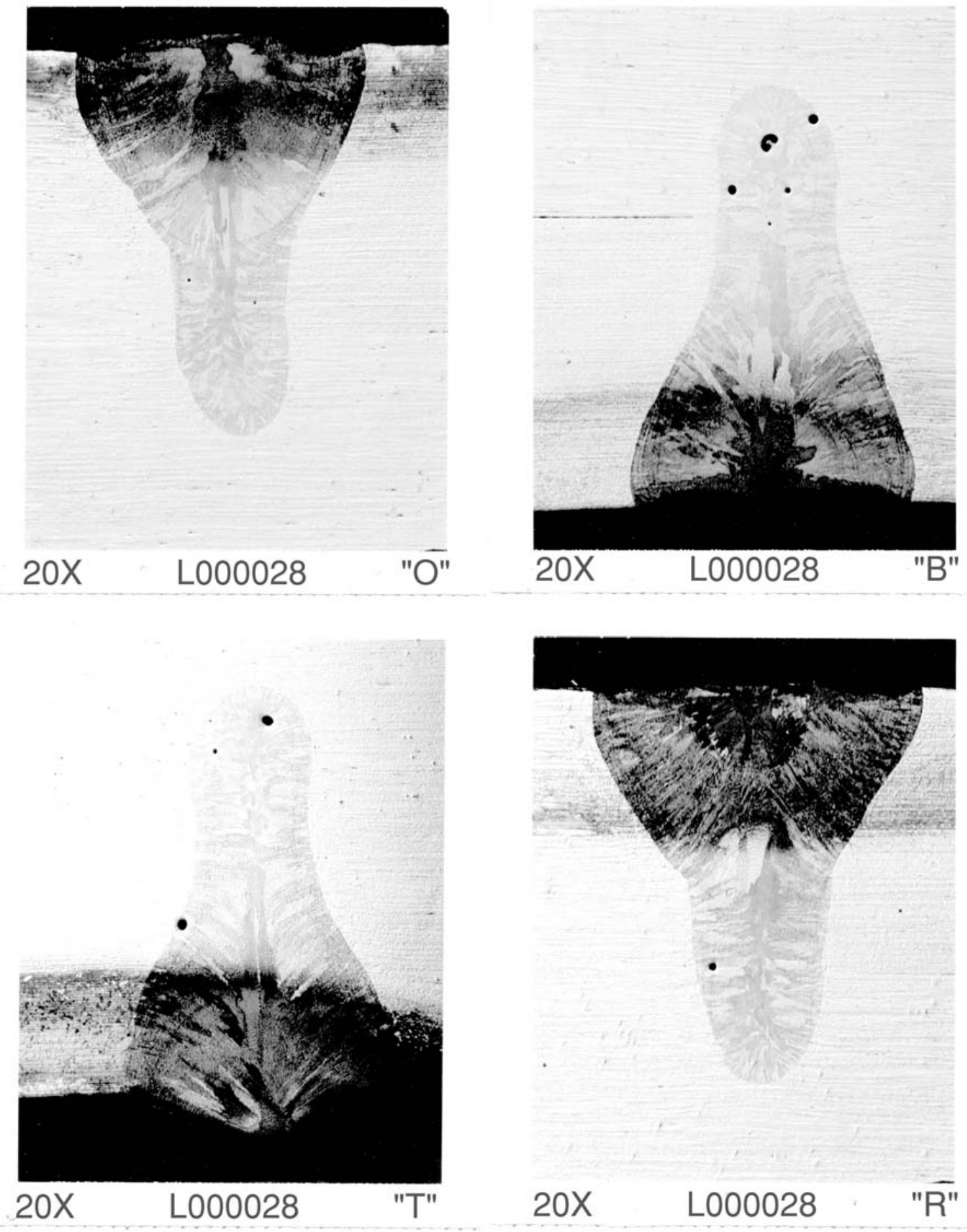
L000029
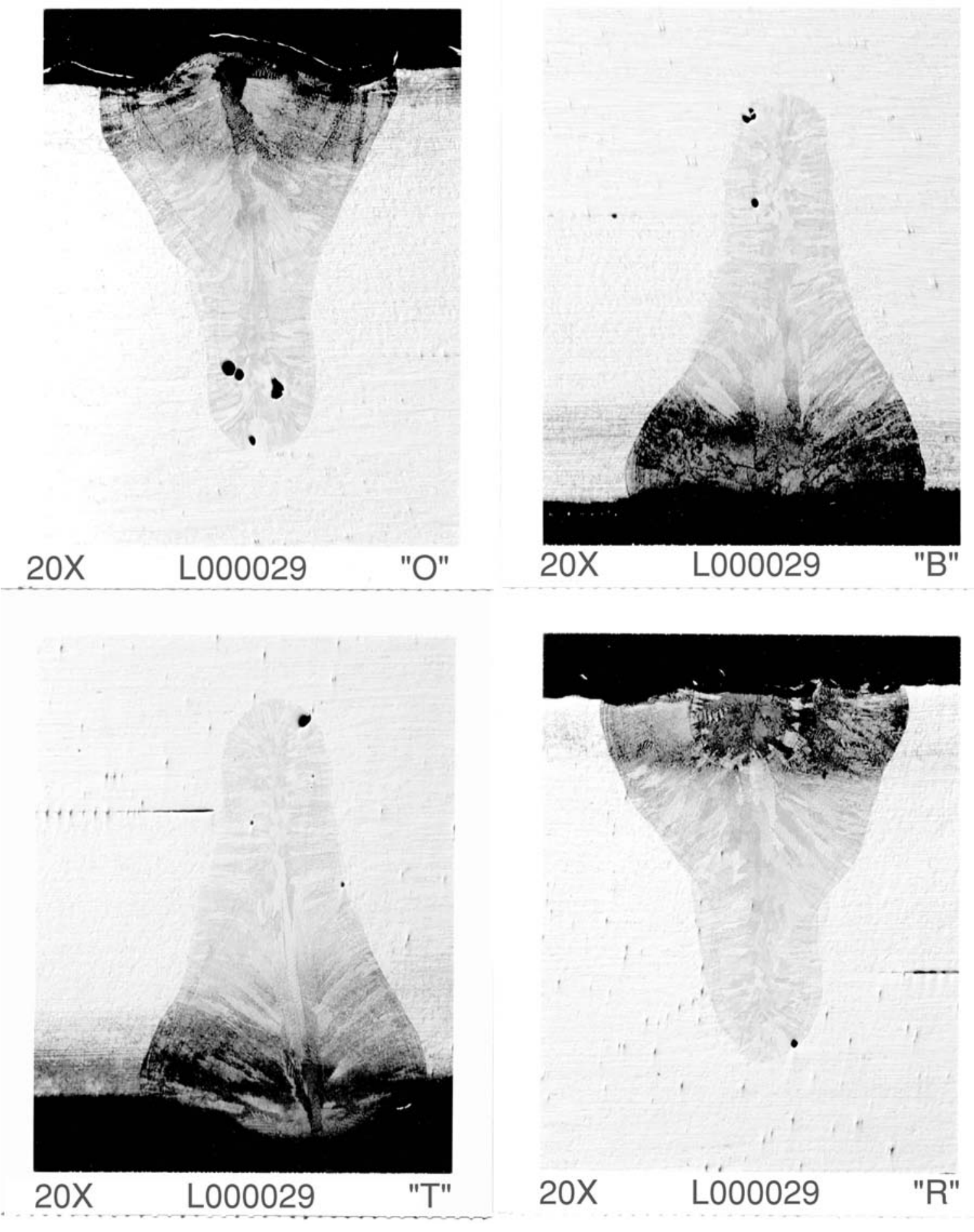
L000030
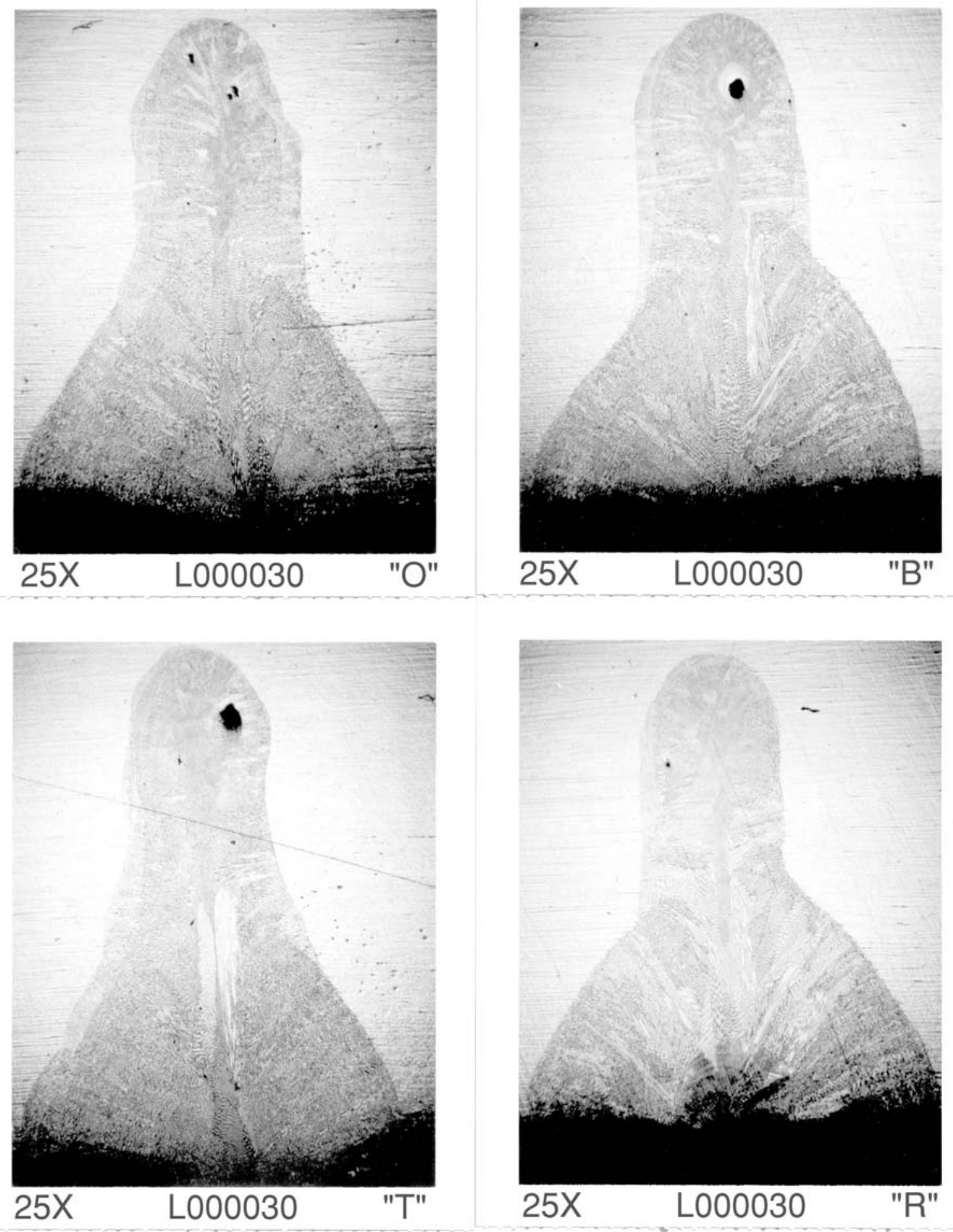
L000031
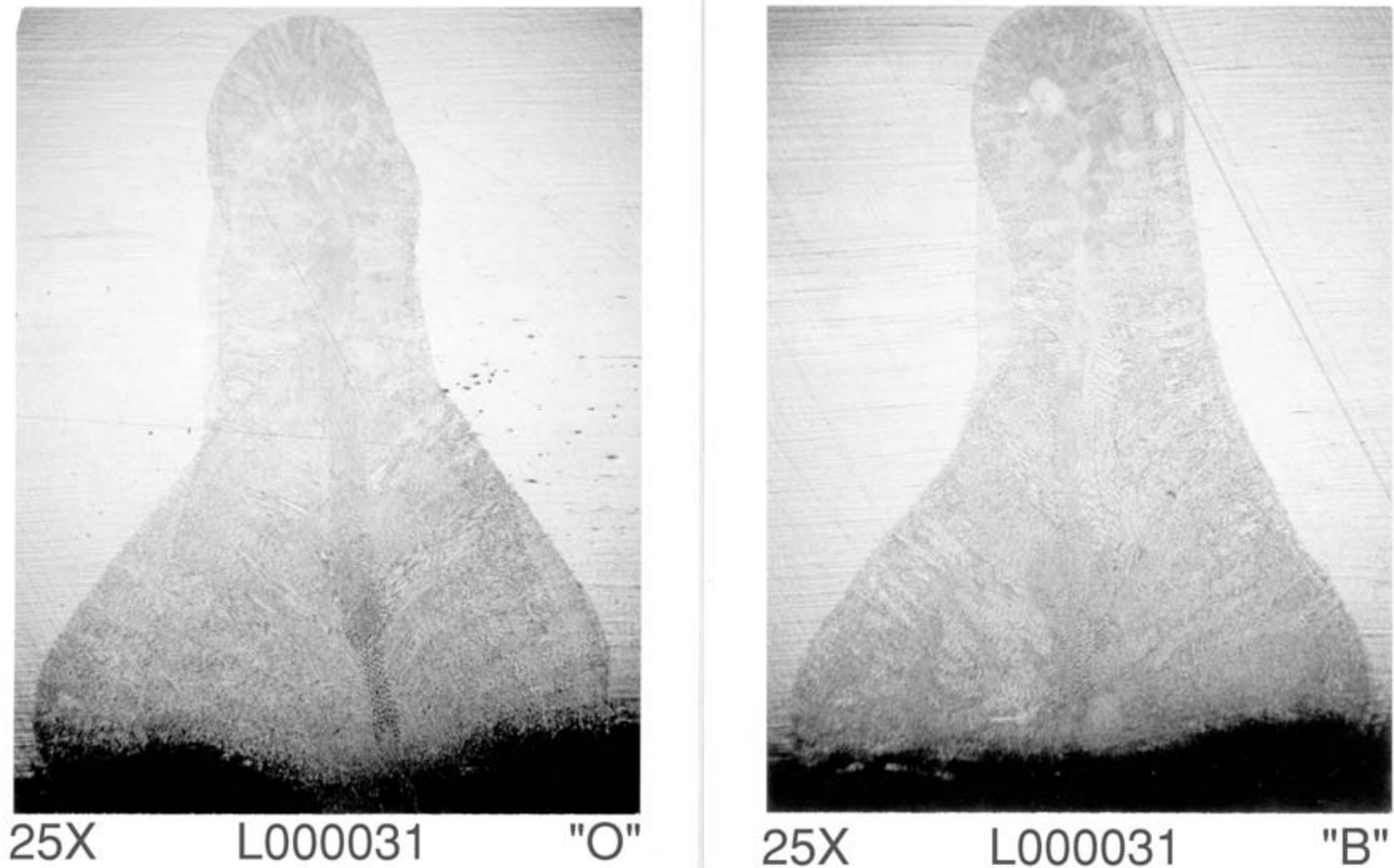

25X L000031

"B"
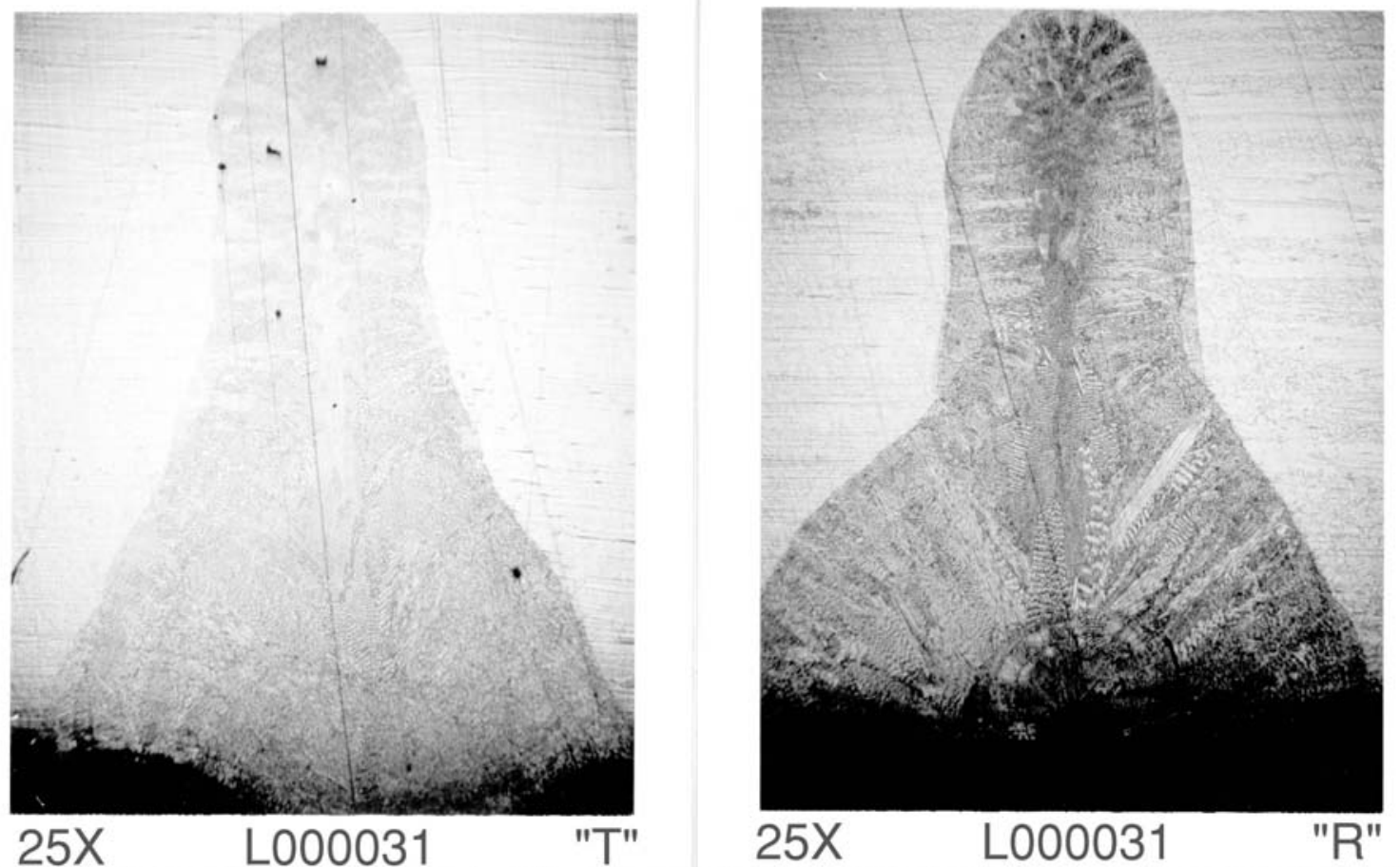
L000032

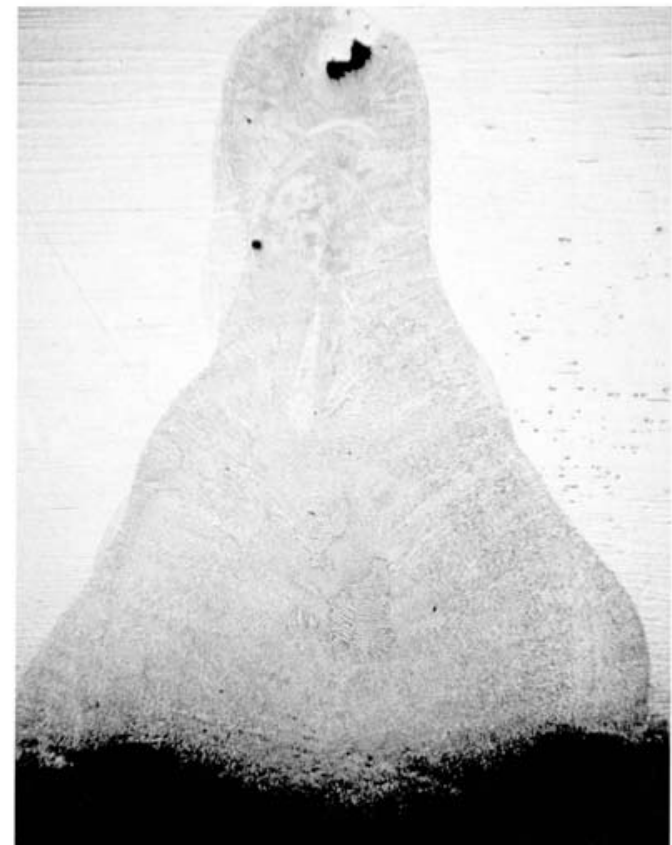

$25 X$

L000032

"O"
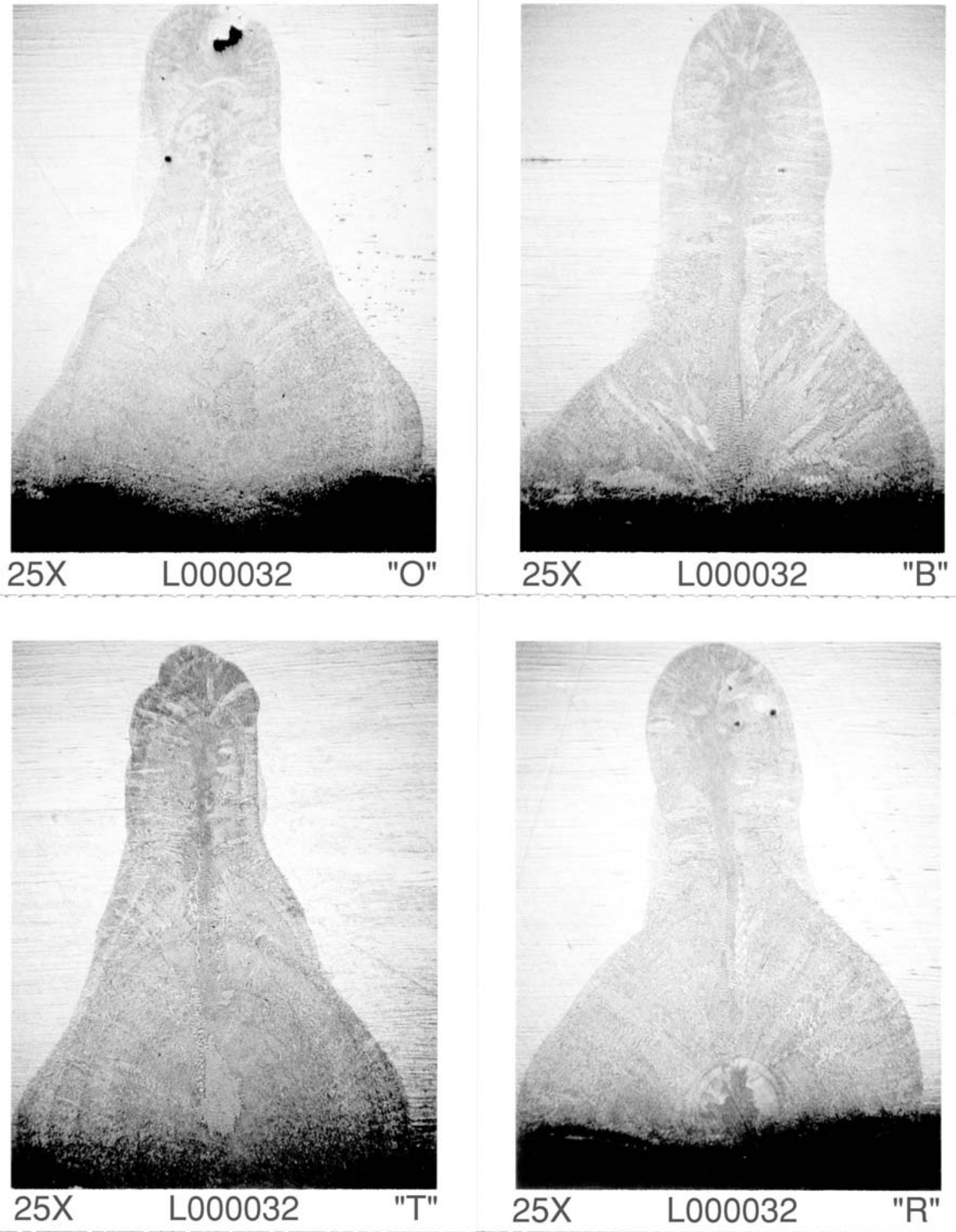
L000033
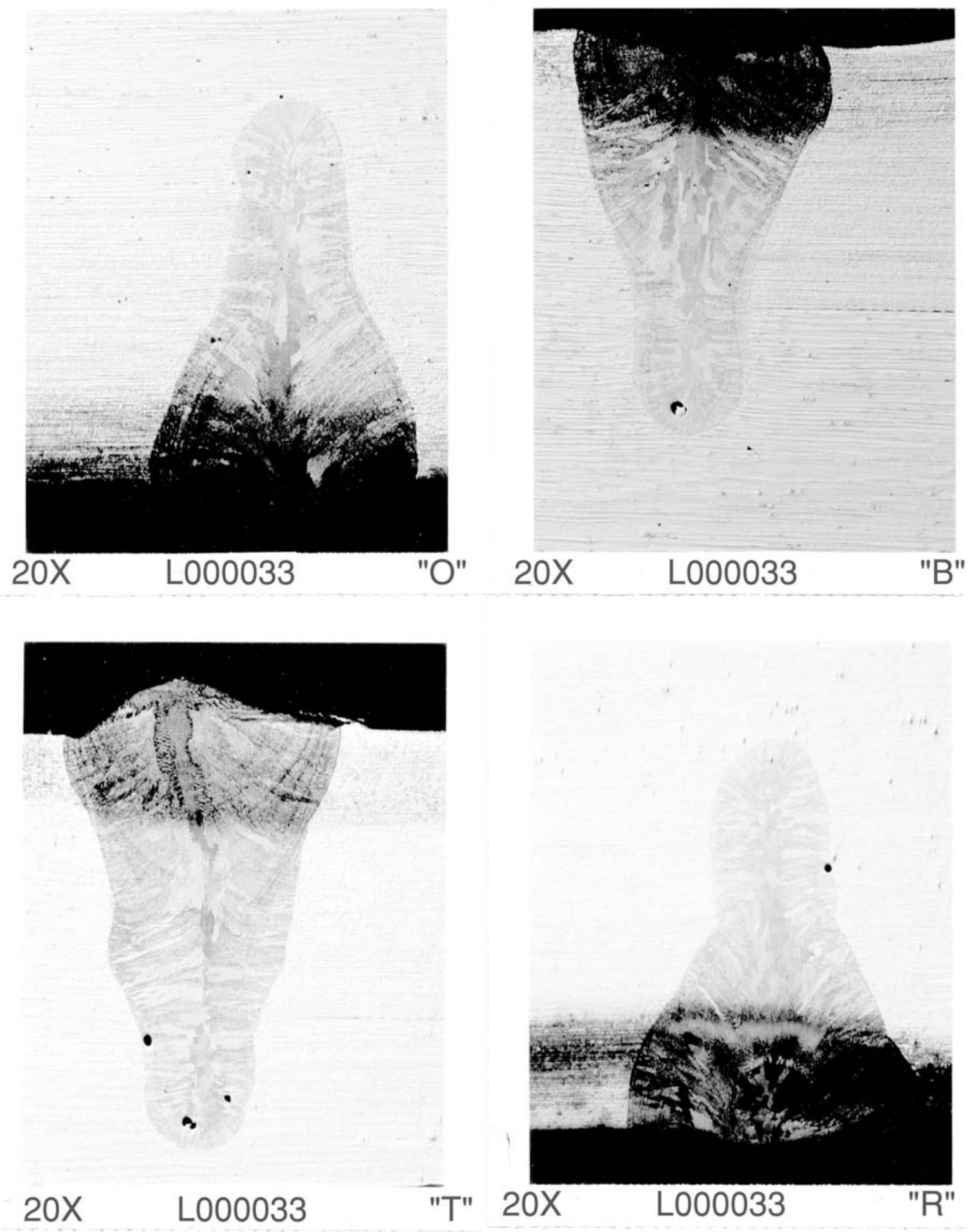


\section{L000036}
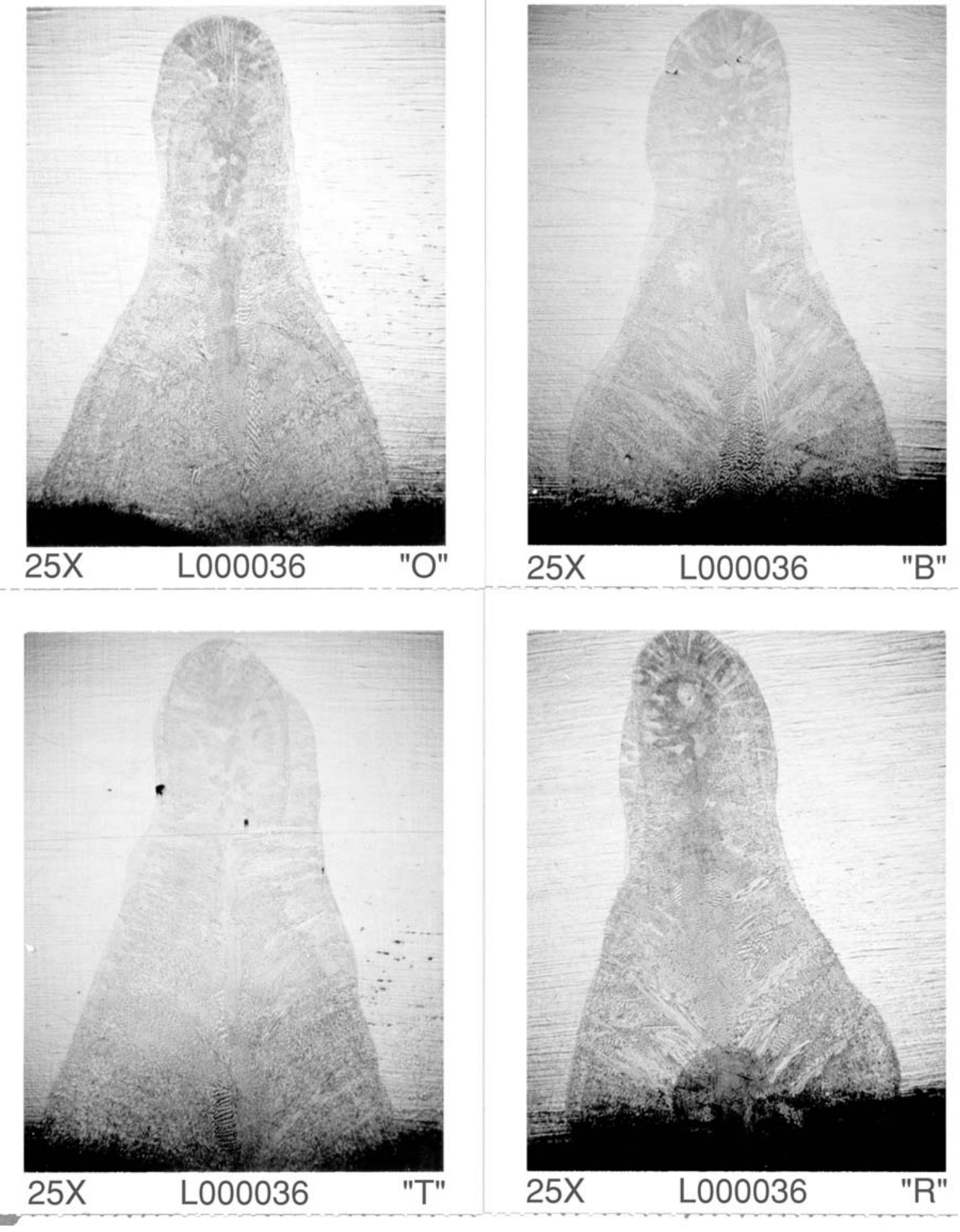
L000037
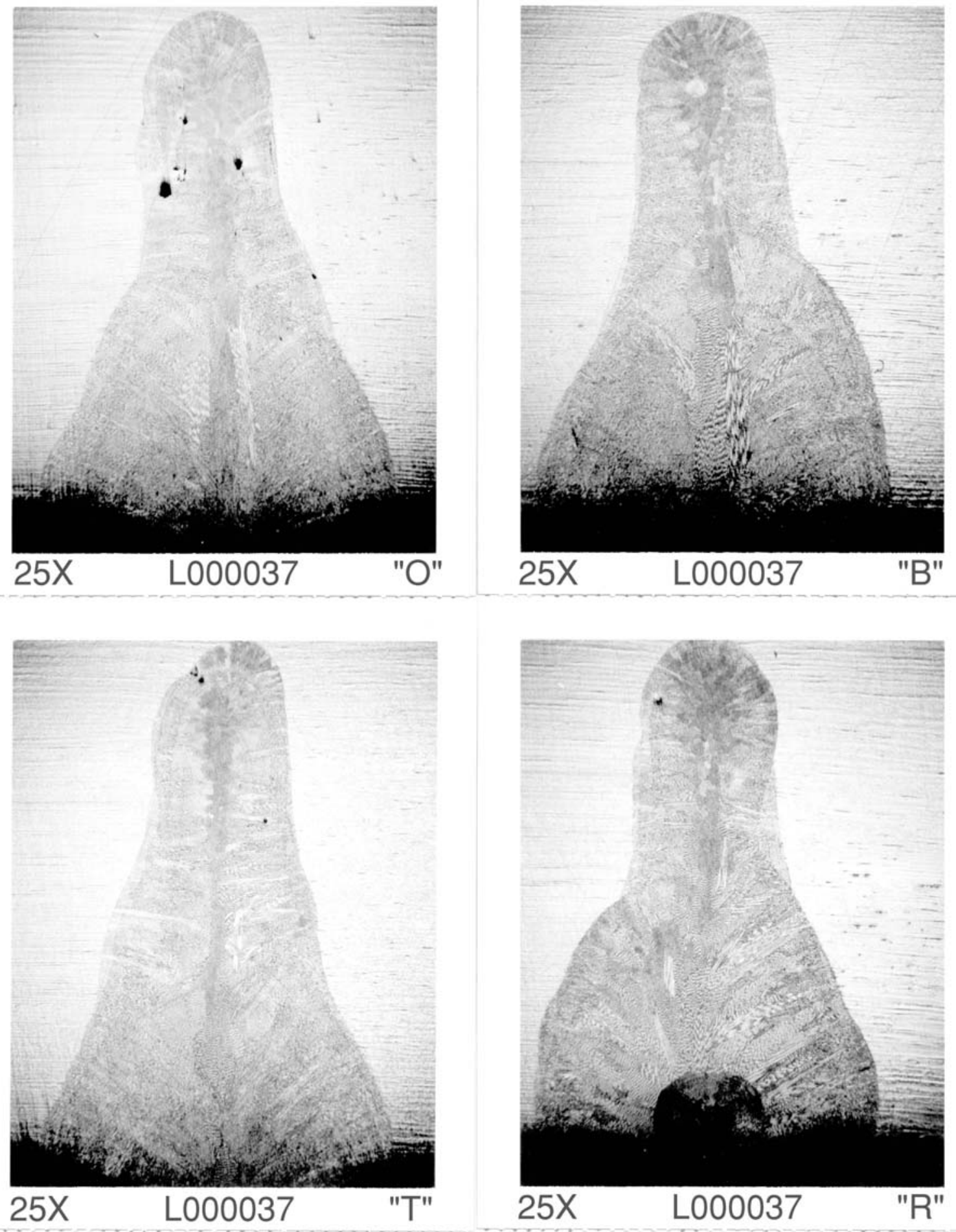
L000038

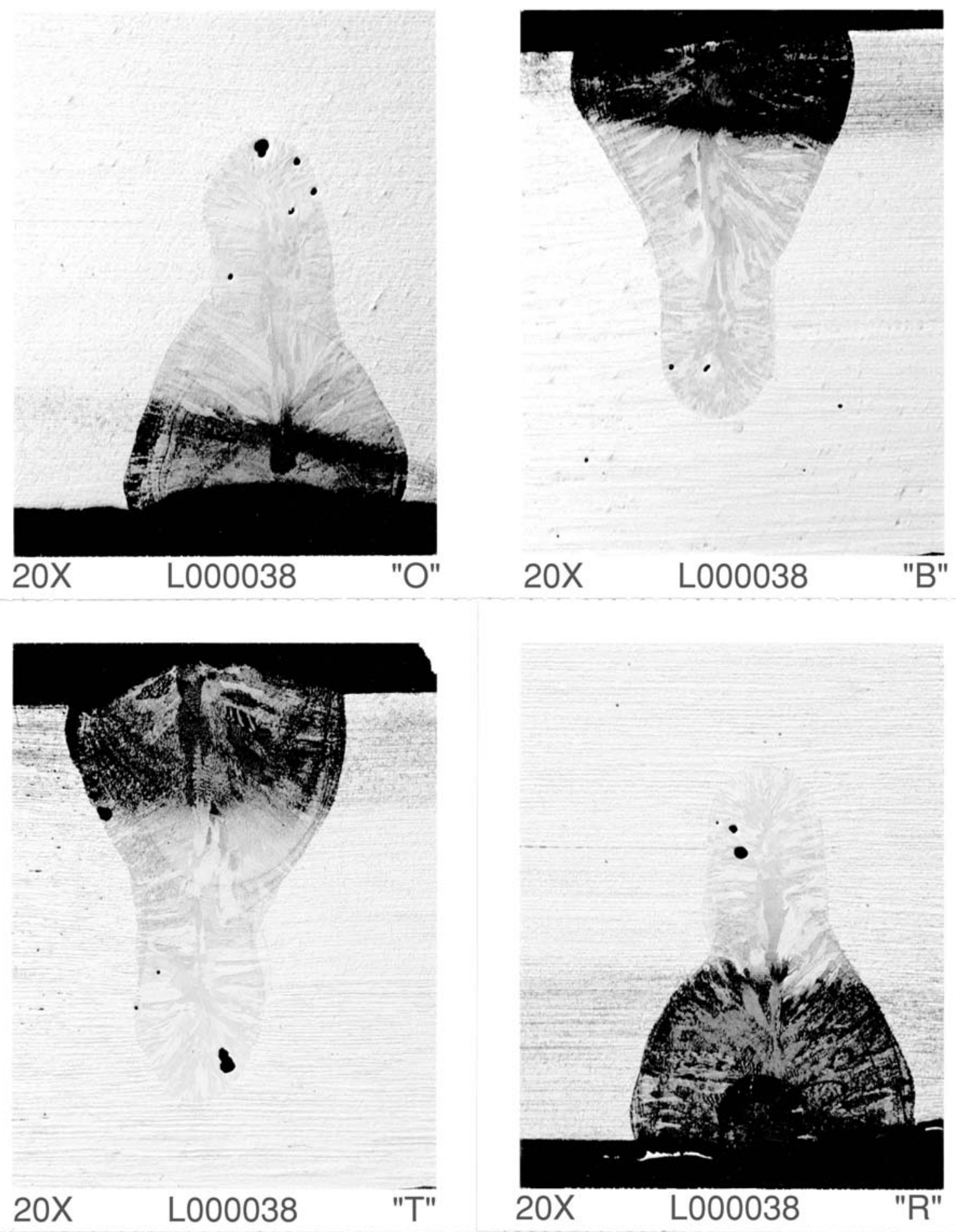



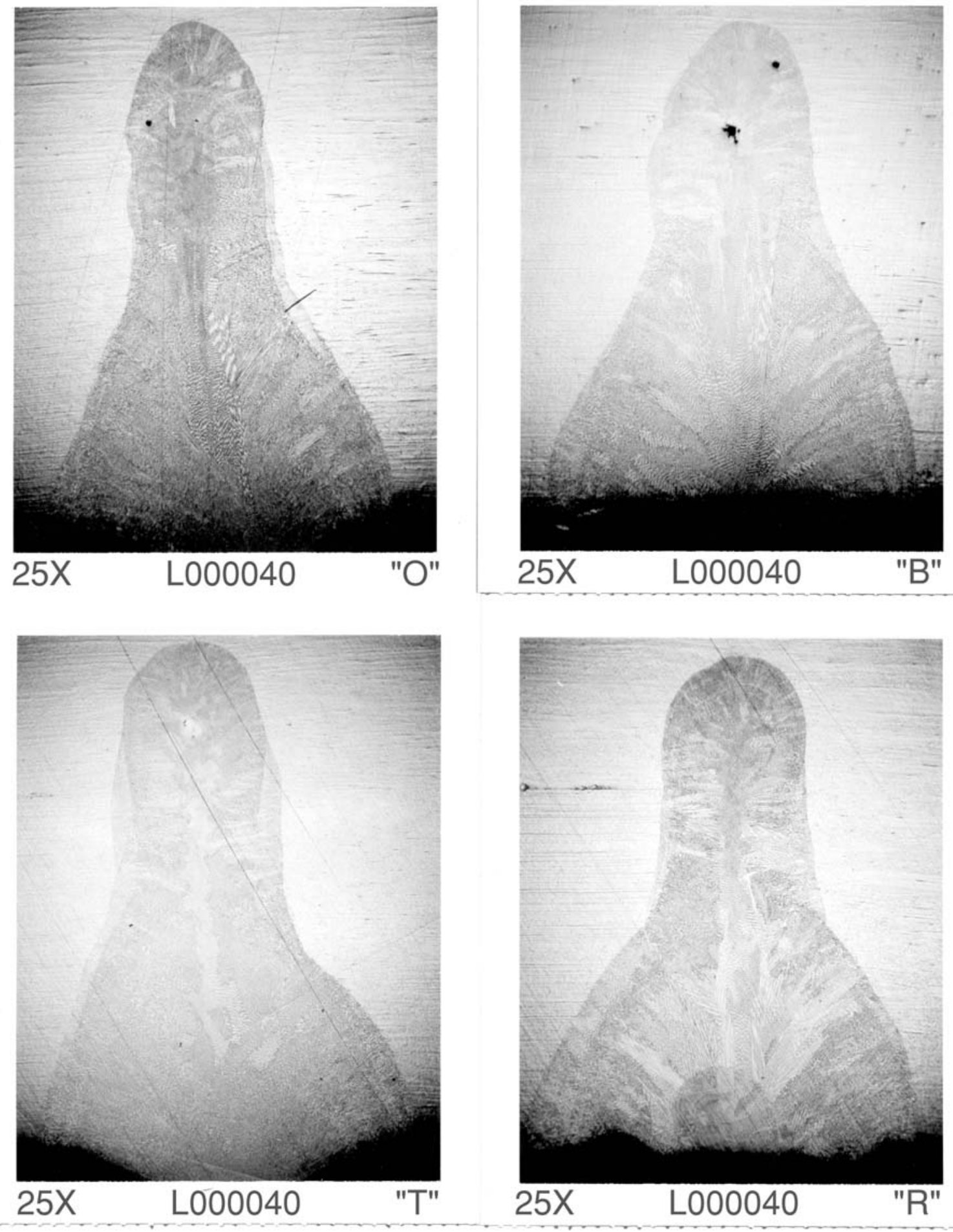
L000045
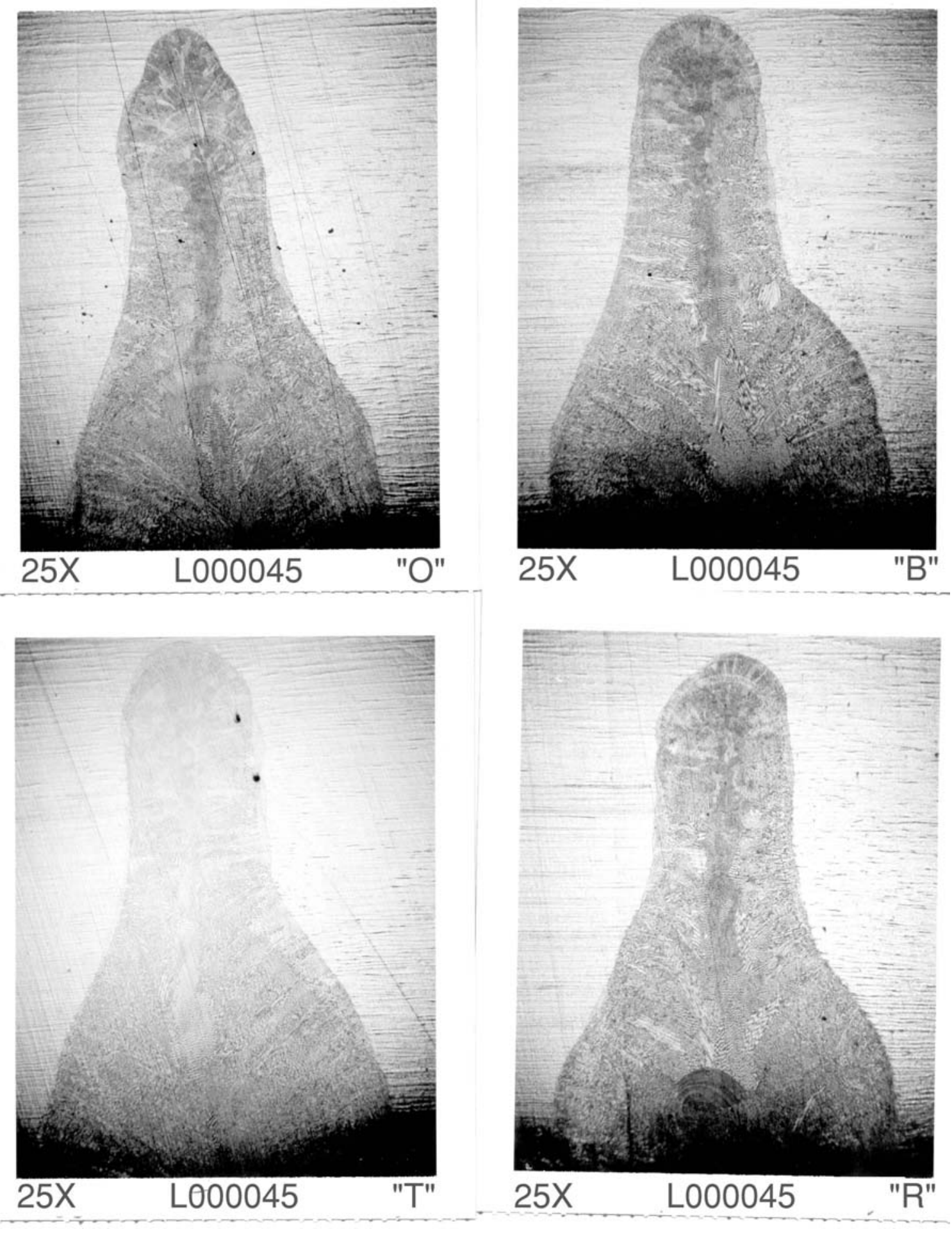
L000046
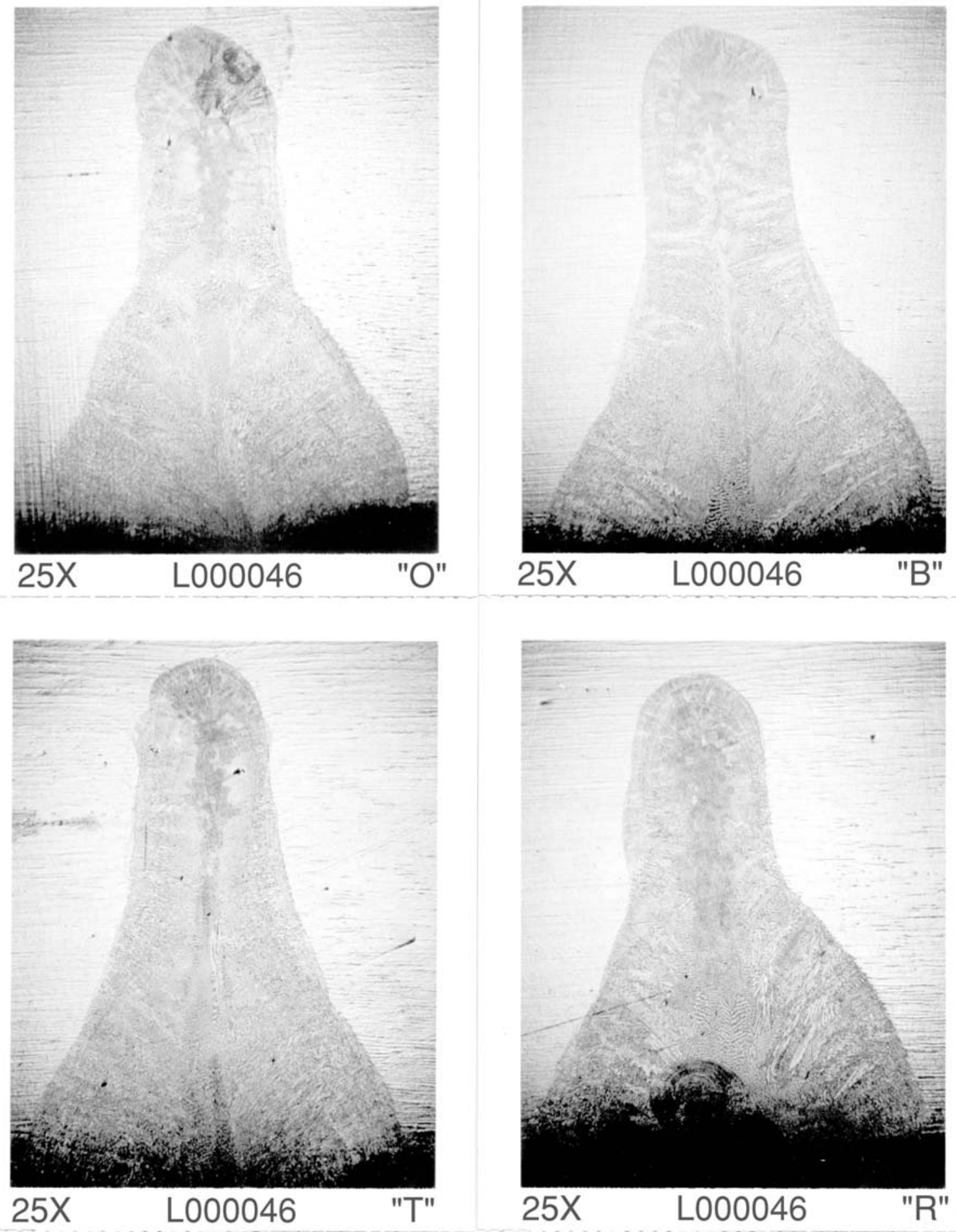
L000047
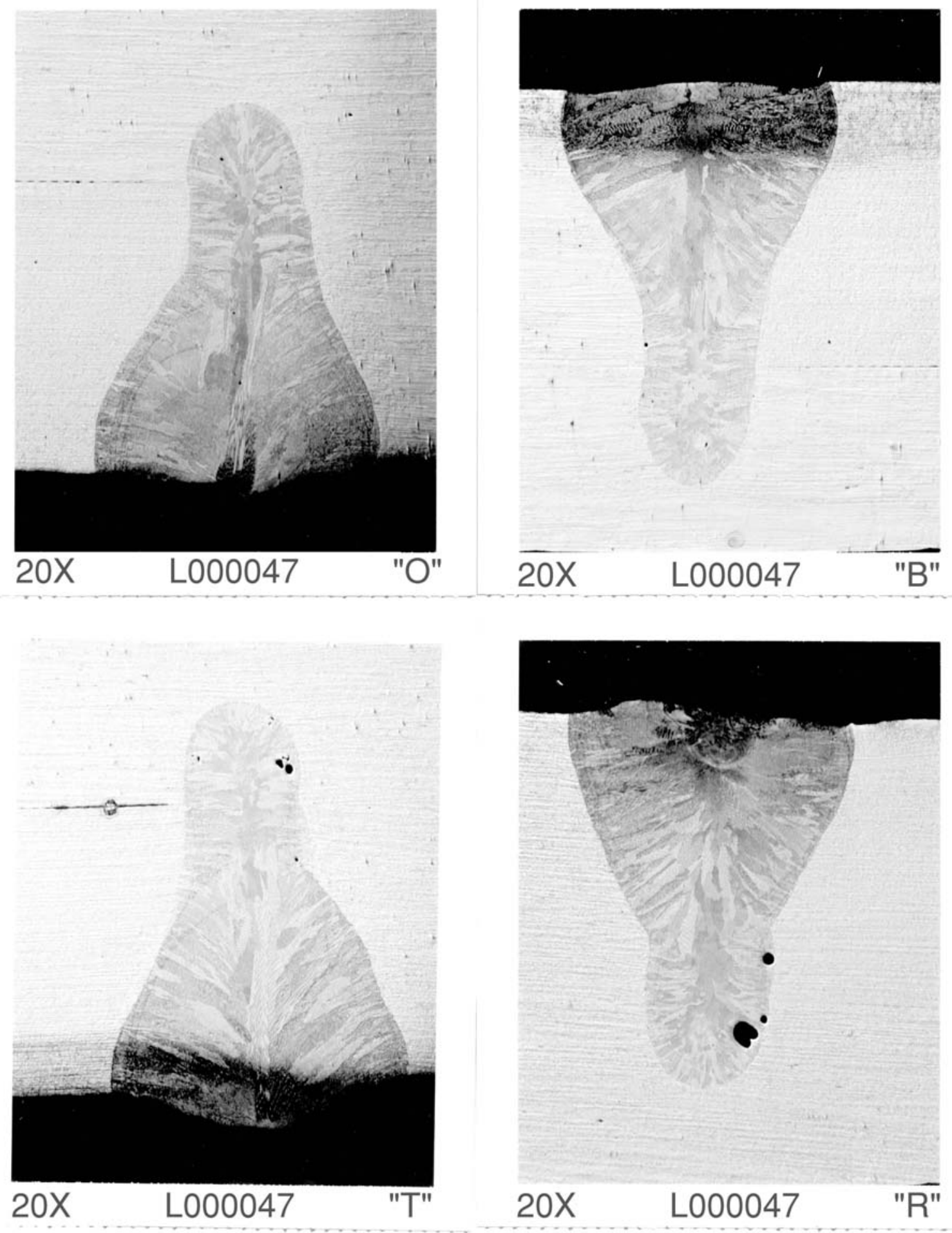